OPEN ACCESS

Edited by:

Toshi Nagata

University of Tokyo, Japan

Reviewed by:

X. Antón Álvarez-Salgado,

Spanish National Research Council,

Spain

Gerhard Kattner,

Alfred Wegener Institute, Germany

${ }^{*}$ Correspondence:

Yuan Shen

shen2@email.sc.edu

Specialty section: This article was submitted to Marine Biogeochemistry, a section of the journal Frontiers in Marine Science

Received: 17 August 2016 Accepted: 26 September 2016

Published: 18 October 2016

Citation:

Shen Y, Benner R, Robbins LL and Wynn JG (2016) Sources, Distributions, and Dynamics of Dissolved Organic Matter in the Canada and Makarov Basins.

Front. Mar. Sci. 3:198.

doi: 10.3389/fmars.2016.00198

\section{Sources, Distributions, and Dynamics of Dissolved Organic Matter in the Canada and Makarov Basins}

\author{
Yuan Shen ${ }^{1 *}$, Ronald Benner ${ }^{1,2}$, Lisa L. Robbins ${ }^{3}$ and Jonathan G. Wynn ${ }^{4}$ \\ ${ }^{1}$ Marine Science Program, University of South Carolina, Columbia, SC, USA, ${ }^{2}$ Department of Biological Sciences, University \\ of South Carolina, Columbia, SC, USA, ${ }^{3}$ US Geological Survey, St. Petersburg Coastal and Marine Science Center, St. \\ Petersburg, FL, USA, ${ }^{4}$ School of Geosciences, University of South Florida, Tampa, FL, USA
}

A comprehensive survey of dissolved organic carbon (DOC) and chromophoric dissolved organic matter (CDOM) was conducted in the Canada and Makarov Basins and adjacent seas during 2010-2012 to investigate the dynamics of dissolved organic matter (DOM) in the Arctic Ocean. Sources and distributions of DOM in polar surface waters were very heterogeneous and closely linked to hydrological conditions. Canada Basin surface waters had relatively low DOC concentrations (69 $\left.\pm 6 \mu \mathrm{mol} \mathrm{L}^{-1}\right)$, CDOM absorption ( $\left.a_{325}: 0.32 \pm 0.07 \mathrm{~m}^{-1}\right)$ and CDOM-derived lignin phenols $\left(3 \pm 0.4 \mathrm{nmol} \mathrm{L}^{-1}\right)$, and high spectral slope values $\left(S_{275-295}: 31.7 \pm 2.3 \mu \mathrm{m}^{-1}\right)$, indicating minor terrigenous inputs and evidence of photochemical alteration in the Beaufort Gyre. By contrast, surface waters of the Makarov Basin had elevated DOC $\left(108 \pm 9 \mu \mathrm{mol} \mathrm{L}^{-1}\right)$ and lignin phenol concentrations $\left(15 \pm 3 \mathrm{nmol} \mathrm{L}^{-1}\right)$, high $a_{325}$ values $\left(1.36 \pm 0.18 \mathrm{~m}^{-1}\right)$, and low $S_{275-295}$ values (22.8 $\pm 0.8 \mathrm{\mu m}^{-1}$ ), indicating pronounced Siberian river inputs associated with the Transpolar Drift and minor photochemical alteration. Observations near the Mendeleev Plain suggested limited interactions of the Transpolar Drift with Canada Basin waters, a scenario favoring export of Arctic DOM to the North Atlantic. The influence of sea-ice melt on DOM was region-dependent, resulting in an increase (Beaufort Sea), a decrease (Bering-Chukchi Seas), and negligible change (deep basins) in surface DOC concentrations and $a_{325}$ values. Halocline structures differed between basins, but the Canada Basin upper halocline and Makarov Basin halocline were comparable in their average DOC (65-70 $\left.\mu \mathrm{mol} \mathrm{L}^{-1}\right)$ and lignin phenol concentrations $\left(3-4 \mathrm{nmol} \mathrm{L}{ }^{-1}\right)$ and $S_{275-295}$ values $\left(22.9-23.7 \mu \mathrm{m}^{-1}\right)$. Deep-water DOC concentrations decreased by 6-8

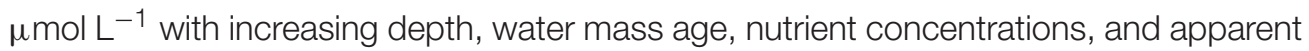
oxygen utilization. Maximal estimates of DOC degradation rates $\left(0.036-0.039 \mu \mathrm{mol} \mathrm{L}^{-1}\right.$ $\mathrm{yr}^{-1}$ ) in the deep Arctic were lower than those in other ocean basins, possibly due to low water temperatures. DOC concentrations in bottom waters (>2500 m; $46 \pm 2 \mu \mathrm{mol}$ $\mathrm{L}^{-1}$ ) of the Canada and Makarov Basins were slightly lower than those reported for deep waters of the Eurasian Basin and Nordic Seas. Elevated $a_{325}$ values (by 10-20\%) were observed near the seafloor, indicating biological activity in Arctic basin sediments.

Keywords: dissolved organic carbon, chromophoric dissolved organic matter, lignin phenols, Arctic Ocean, Canada Basin, Makarov Basin, transpolar drift, sea-ice melt 


\section{INTRODUCTION}

The Arctic Ocean is a relatively small, enclosed basin characterized by pronounced riverine influence and complex hydrography. This region accounts for only $1 \%$ of the global ocean volume but captures $\sim 11 \%$ of global riverine freshwater and organic carbon (Opsahl et al., 1999; Jakobsson et al., 2004; Rachold et al., 2004). Ocean waters from the North Pacific and Atlantic enter the Arctic Ocean via the Bering Strait and the Nordic Seas (Rudels, 2009). Much of the water and dissolved organic matter (DOM) entering the Arctic is modified by biological and physicochemical processes, such as sea-ice formation and melting, during passage over the extensive continental shelves and residence in basins (Jones and Anderson, 1986; Cooper et al., 2005; Shen et al., 2012). Modification of waters on continental shelves supplies dense water and bioreactive elements to the basin interior.

The distributions and fates of DOM in the Arctic Ocean have been the focus of research for understanding both regional and global carbon cycles (Gordon and Cranford, 1985; Wheeler et al., 1997; Benner et al., 2005; Anderson and Amon, 2015). Previous studies have noted considerable spatial and temporal heterogeneity in the abundance and distribution of DOM (Wheeler et al., 1997; Guay et al., 1999; Benner et al., 2005; Mathis et al., 2005; Letscher et al., 2011). Analysis of dissolved lignin phenols reveals strong and variable terrigenous signatures throughout polar surface waters (Opsahl et al., 1999; Benner et al., 2004, 2005). Terrigenous DOM is transported from continental shelves to interior basins by a variety of pathways (Fichot et al., 2013). The routing of continental runoff is susceptible to local wind patterns, and it exerts a strong influence on the transit of DOM along and across the broad shelves (Guay et al., 2001; Fichot et al., 2013; Carmack et al., 2015). Upon exiting the shelf, DOM is entrained into the basin-scale wind-driven circulation and redistributed in the basins for varying periods of time (up to $20 \mathrm{yr}$ ) prior to export to the north Atlantic Ocean (Bauch et al., 1995; Rutgers van der Loeff et al., 1995; Hansell et al., 2004).

Wind-driven circulation in the upper Arctic Ocean includes the anticyclonic Beaufort Gyre centered in the southern Canada Basin and the Transpolar Drift extending from the Siberian margin to Fram Strait (Rudels, 2009). The Beaufort Gyre creates a strong convergence that favors long-term retention and processing of DOM within the gyre, whereas the fast-moving Transpolar Drift serves to export DOM with less alteration (Mysak, 2001; Bluhm et al., 2015). These two circulation systems drive large cross-basin variability in the distributions and fates of DOM (Hansell et al., 2004; Benner et al., 2005). Previous measurements of dissolved organic carbon (DOC), lignin phenols, and chromophoric DOM (CDOM) absorption in polar surface waters have indicated a much stronger terrigenous signal over the Makarov Basin than in the adjacent Mendeleev Plain and Canada Basin (Guay et al., 1999; Benner et al., 2005; Letscher et al., 2011; Guéguen et al., 2015). However, variations in atmospheric forcing can alter the axis of the Transpolar Drift and force a sizable portion of Siberian runoff and terrigenous DOM into the Beaufort Gyre for extended periods (Proshutinsky and Johnson, 1997; Mysak, 2001; Morison et al., 2012), thereby resulting in less export of Arctic DOM to the North Atlantic Ocean. A more detailed survey of DOM components is needed to better capture this spatial and temporal variability and to understand responses to climate change.

The impact of sea-ice melt on DOC and CDOM concentrations and distributions is also variable and difficult to resolve. Several studies in the Chukchi Sea have reported that melting of sea ice dilutes concentrations of DOC and CDOM in surface waters (Mathis et al., 2005, 2007; Logvinova et al., 2016). By contrast, observations on river-influenced shelves indicate a high abundance of terrigenous material in sea ice and the potential for increasing DOC concentrations with sea-ice melting (Eicken, 2004; Eicken et al., 2005). Concentrations of DOC determined in several ice cores from the Arctic basins are highly variable $\left(\sim 100\right.$ to over $\left.700 \mu \mathrm{mol} \mathrm{L}{ }^{-1}\right)$ (Thomas et al., 1995; Melnikov, 1997; Opsahl et al., 1999), and melting of this ice would result in a slight increase or a negligible change in surface mixed layer DOC concentrations (Anderson, 2002; Anderson and Amon, 2015). The varying results of these studies suggest the impact of sea ice on DOM is region-dependent and warrants further study.

Relatively few studies have presented DOC concentrations in deep waters of the Arctic Ocean. With a few exceptions (Anderson et al., 1994; Bussmann and Kattner, 2000), most studies have reported moderate variability $\left(5-10 \mu \mathrm{mol} \mathrm{L}^{-1}\right)$ in DOC concentrations at depths $>1000 \mathrm{~m}$ (Amon, 2004; Benner et al., 2005; Davis and Benner, 2005; Mathis et al., 2005; Griffith et al., 2012). It is less clear how DOM is distributed throughout the deep Arctic. Profiles of transient tracers (e.g., chlorofluorocarbons) in the Arctic basins indicate the mean ventilation age of water increases with depth in the deep layer (>1000 m; 100-300 yr; Tanhua et al., 2009). Griffith et al. (2012) examined two full-depth profiles of the $\Delta^{14} \mathrm{C}$ of DOC in the Canada Basin and their data show a notable decrease in $\Delta^{14} \mathrm{C}$ with increasing depth from 1000 to $2500 \mathrm{~m}$ (Griffith et al., 2012). The observed variations in the age of water and DOC suggest that DOC could be degraded in the deep Arctic and may exhibit unique vertical concentration gradients absent in other ocean basins.

The primary objective of this study is to improve understanding of the sources, concentrations and distributions of DOM, and the processes that shape patterns of spatial and temporal variability. We present a comprehensive data set of DOC, CDOM, and CDOM-derived lignin phenol concentrations in waters of the western Arctic Ocean, extending from the Chukchi and Beaufort shelves, across the Chukchi Borderland and Canada Basin, and poleward to the Mendeleev Plain and Makarov Basin. Sources of freshwater are quantified to examine the regional influence of meteoric water and sea-ice melt on DOM in polar surface waters. The patterns observed in Arctic surface waters are discussed in the context of climate-driven changes in circulation. In addition, depth profiles are analyzed to evaluate vertical variability in DOC and CDOM across the Canada and Makarov Basins, with a particular emphasis on halocline and deep waters. 


\section{METHODS}

\section{Study Region and Sample Collection}

Water samples were collected during three summer cruises (August-September) on the USCGC Healy in 2010, 2011, and 2012 (HLY1002, HLY1102, HLY1202; Figure 1; Robbins et al., 2013a,b,c, 2014). Surface waters were collected at a depth of $\sim 8 \mathrm{~m}$ using an underway flow-through system. Profile samples were collected at various depths $(2-3800 \mathrm{~m})$ at 17 stations using a rosette sampler equipped with 24 Niskin bottles and a Conductivity-Temperature-Depth (CTD) probe (SeaBird SBE45) used to measure water salinity, temperature, and pressure. A total of 770 water samples were collected for analyses of DOC, CDOM, and $\delta^{18} \mathrm{O}$, with about 700 matching samples for inorganic nutrient analysis. Samples for measurements of DOC and CDOM were collected in pre-cleaned $60-\mathrm{mL}$ amber glass bottles and frozen immediately at $-20^{\circ} \mathrm{C}$ until analysis in the laboratory. Samples for measurement of nutrient concentrations (phosphate, nitrate + nitrite, ammonium, and silicate) were frozen immediately at $-80^{\circ} \mathrm{C}$ in scintillation vials prior to analysis. Samples for measurement of oxygen isotopic composition ( $\delta^{18} \mathrm{O}$ values) were collected in glass vials and stored at $4^{\circ} \mathrm{C}$ prior to analysis. Nutrient analyses were completed using a SEAL AA3 four-channel segmented flow analyzer at the Nutrient Analytical Facility at the Woods Hole Oceanographic Institution, Woods Hole, MA. Additional total silicon concentrations were measured on separate samples using an Agilent Inductivelycoupled Plasma Mass Spectrometry at the University of South Florida, St. Petersburg, FL. $\delta^{18} \mathrm{O}$ values are reported on the Standard Mean Ocean Water (SMOW) international reference scale and were measured by Isotope Ratio Mass Spectrometry (Thermo Finnigan Delta V) at the University of South Florida, Tampa, FL.

The broad spatial scale of sampling in this study covered a wide range of environments that varied substantially in seaice cover (Figure 1). Surface waters in the Bering Sea, Chukchi Sea, and southern Canada Basin were mostly ice-free, whereas areas north of $80^{\circ} \mathrm{N}$ were largely covered by sea ice during the sampling periods. Sea-ice area in the Arctic Ocean reached a low of $3.0 \times 10^{6} \mathrm{~km}^{2}$ during the HLY1202 cruise (Parkinson and Comiso, 2013). Comparisons in summer sea ice cover among 2010, 2011, and 2012 revealed a notable ice reduction in 2012 in the northern Chukchi Borderland, southern Mendeleev Plain, and the central and southern areas of the Canada Basin (Figure 1). In this study, the geographic names and boundaries of oceanic regions were defined according to Marine Regions (http://www.marineregions.org) with modifications.

\section{Analyses of DOC and CDOM, and Estimation of Dissolved Lignin Concentrations}

Water samples for measurements of DOC and CDOM were thawed and filtered in the laboratory through pre-combusted $\left(450^{\circ} \mathrm{C}, 4 \mathrm{~h}\right)$ Whatman $\mathrm{GF} / \mathrm{F}$ filters $(0.7-\mu \mathrm{m}$ pore size) prior to analysis. Concentrations of DOC were measured by high temperature combustion using a Shimadzu total organic carbon (TOC) TOC-V $V_{C S N}$ analyzer equipped with an autosampler.
The Shimadzu platinum catalyst was conditioned by repeated injections of acidified Milli Q UV-Plus water ( $\mathrm{pH} 2-3$ ) prior to sample analysis (Benner and Strom, 1993). Before injection, samples were acidified with $2 \mathrm{~mol} \mathrm{~L}^{-1}$ hydrochloric acid ( $\left.\mathrm{HCl}\right)$ to pH 2-3 and were sparged with ultra-high purity oxygen for $2 \mathrm{~min}$ to remove the inorganic carbon as $\mathrm{CO}_{2}$. The injection volume was $100-\mu \mathrm{L}$. Milli Q water and deep-sea reference standards (University of Miami) were injected every 6th sample. Values of blanks (Milli Q UV-Plus water) were negligible throughout the measurements of seawater samples. The coefficient of variation (CV) of four repeated injections of a given sample was typically $\pm 0.9 \%$. The final concentrations of DOC were quantified using an external calibration curve generated with five concentrations of standards (glucosamine; Sigma Chemical CO.) that bracketed the range of values observed in the samples.

Absorbance spectra $(250-800 \mathrm{~nm})$ of filtered water samples were measured using a Shimadzu ultraviolet-visible 1601 dualbeam spectrophotometer and 5-cm cylindrical quartz cuvettes. Water samples were warmed to room temperature prior to analysis. Absorbance was blank corrected (the average absorbance between 690 and $700 \mathrm{~nm}$ ) and then converted to Napierian absorption coefficient, $a_{\lambda}\left(\mathrm{m}^{-1}\right)$, using Equation (1)

$$
a_{\lambda}=2.303 \frac{A_{\lambda}}{r}
$$

where $A_{\lambda}$ is the absorbance measured across path length $r$ at a wavelength of $\lambda$. The spectral slope coefficient $(S)$ was calculated using a linear regression of log-linearized $a_{\lambda_{1}}$ as in Equation (2)

$$
a_{\lambda_{1}}=a_{\lambda_{2}} \exp \left[-S\left(\lambda_{1}-\lambda_{2}\right)\right]
$$

where, $a_{\lambda_{1}}$ and $a_{\lambda_{2}}$ are absorption coefficients at wavelengths $\lambda_{1}$ and $\lambda_{2}\left(\lambda_{1}>\lambda_{2}\right)$. $S$ in the $275-295 \mathrm{~nm}$ spectral range is reported as $S_{275-295}$ with units of $\mu \mathrm{m}^{-1}$.

Concentrations of dissolved lignin phenols were retrieved from CDOM absorption coefficients as in Fichot et al. (2016), using Equations $(3,4)$. When $a_{250}$ is $<4 \mathrm{~m}^{-1}$,

$$
\ln \left(\mathrm{TDLP}_{9}\right)=0.7672 \times a_{263}-0.3987
$$

when $a_{250}$ is $\geq 4 \mathrm{~m}^{-1}$,

$$
\begin{aligned}
\ln \left(\mathrm{TDLP}_{9}\right)= & -2.282 \times \ln \left(a_{350}\right)-8.209 \times \ln \left(a_{275}\right) \\
& +11.365 \times \ln \left(a_{295}\right)+2.909
\end{aligned}
$$

Concentrations of total dissolved lignin phenols $\left(\right.$ TDLP $\left._{9}\right)$ are the sum of nine dissolved lignin phenols ( $p$-hydroxybenzaldehyde, p-hydroxyacetophenone, p-hydroxybenzoic acid, vanillin, acetovanillone, vanillic acid, syringaldehyde, acetosyringone, and syringic acid) and are reported in units of nmol $\mathrm{L}^{-1}$. These two models were constructed from paired measurements of dissolved lignin and CDOM in oceanic samples that were collected mostly in the Arctic Ocean (Fichot et al., 2016) and are therefore applicable to this study. Herein, the models were applied only to the upper $300 \mathrm{~m}$ of the water column (i.e., polar mixed layer and halocline waters) where riverine inputs were evident from the measured oxygen isotopic composition $\left(\delta^{18} \mathrm{O}\right)$ and calculated meteoric water fraction. 


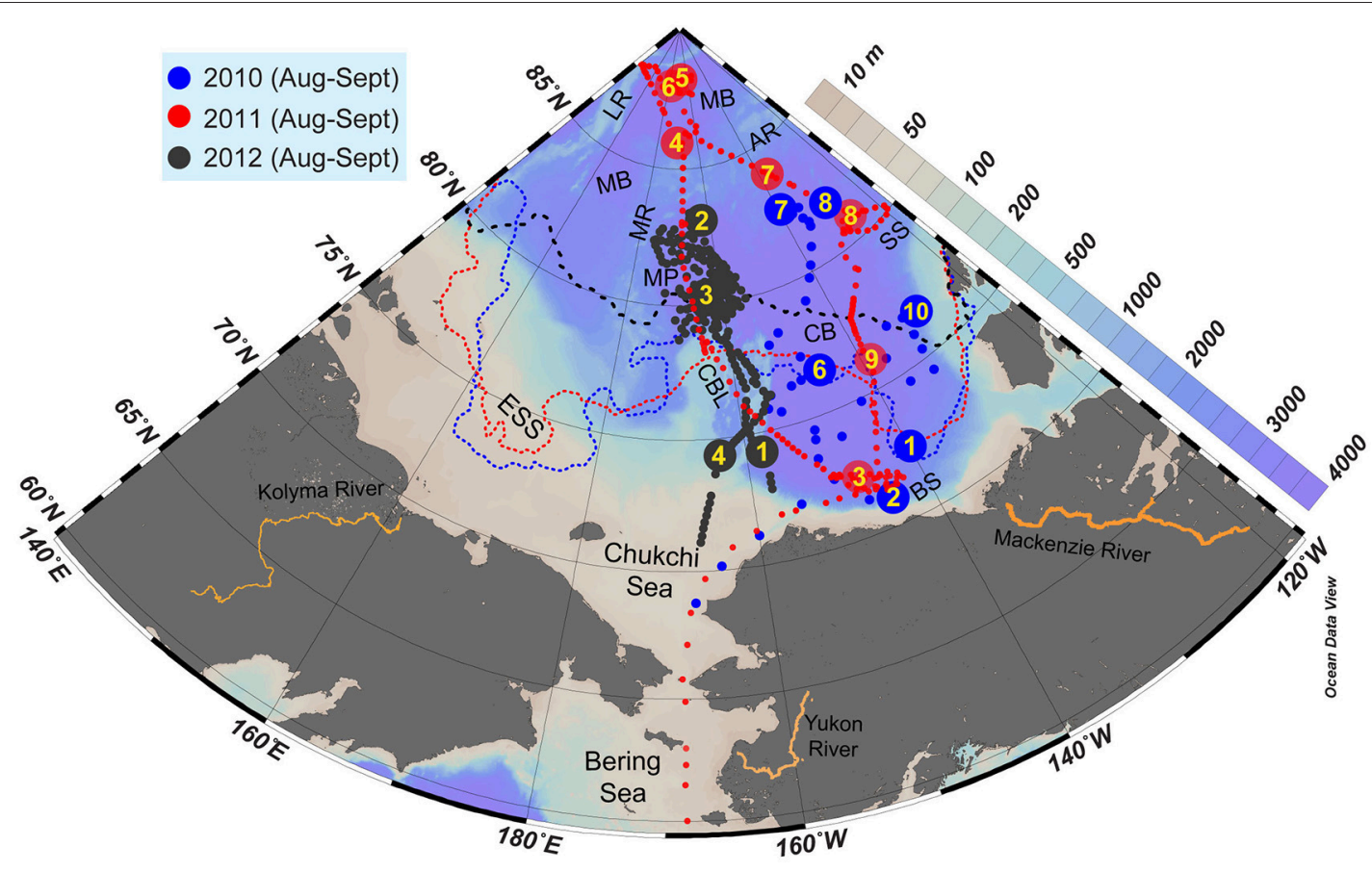

FIGURE 1 | Map of the study region and sampling locations in the western Arctic Ocean. Water samples were collected from the surface (8 m) and depth profiles (2-3800 m; denoted by numbers) during three summer cruises in 2010, 2011, and 2012. The blue, red, and black dashed lines show the average sea-ice edge for September 2010, 2011, and 2012, respectively. AR, Alpha Ridge; BS, Beaufort Sea; CB, Canada Basin; CBL, Chukchi Borderland (Chukchi Plateau, Northwind Plain and Ridge); ESS, East Siberian Sea; LR, Lomonosov Ridge; MB, Makarov Basin; MP, Mendeleev Plain; MR, Mendeleev Ridge; SS, Sever Spur.

\section{CDOM Freeze/Thaw Experiments}

The effects of filtration and freeze/thaw on CDOM properties of seawater were determined using waters collected in the surface $(45 \mathrm{~m})$ and deep $(1200 \mathrm{~m})$ Atlantic Ocean. Six replicates of seawater samples were collected from each depth in precleaned $\left(450^{\circ} \mathrm{C}, 4 \mathrm{~h}\right)$ glass vials. The samples divided into three treatments: (1) filtered and refrigerated at $4^{\circ} \mathrm{C}$; (2) filtered and frozen at $-20^{\circ} \mathrm{C}$; (3) frozen without filtration and filtered prior to analysis. For each treatment, one set of replicates $(n=3)$ was filtered through GF/F filters $(0.7-\mu \mathrm{m}$ pore size; Whatman $\left.{ }^{\circledR}\right)$ and the other set $(n=3)$ was filtered through Supor membranes $\left(0.2-\mu \mathrm{m}\right.$ pore size; Supor ${ }^{\circledR}-200$, Life Sciences). The refrigerated samples were analyzed immediately upon return to the home laboratory (within 6 days of collection), and the frozen samples were stored at $-20^{\circ} \mathrm{C}$ for 28 days before analysis. The analysis of CDOM absorbance and calculations of absorption coefficient $\left(a_{\lambda}\right)$ and spectral slope coefficient $\left(S_{275-295}\right)$ followed procedures described in the previous section.

\section{Quantifying Water Source Contributions}

Seawater in the Arctic Ocean can be characterized as a mixture of freshwater sources, such as meteoric water (MW; precipitation and river runoff) and sea-ice melt (SIM), with seawater sources such as Pacific water (PW), and Atlantic water (ATW). Each water source can be characterized by a distinct combination of chemical tracers that range from conservative (e.g., salinity and oxygen isotopic composition, i.e., $\delta^{18} \mathrm{O}$ values) to semi-conservative (e.g., nutrient concentrations or alkalinity). For example, Arctic MW, including river runoff and direct precipitation, has a distinct combination of very low salinity and nutrient concentrations combined with ${ }^{18} \mathrm{O}$-depleted $\delta^{18} \mathrm{O}$ values $(\approx-20 \%$ ). SIM has low salinity (slightly above zero) and nutrients due to brine rejection, combined with $\delta^{18} \mathrm{O}$ values similar to that of its source water due to a relatively small ${ }^{18} \mathrm{O} /{ }^{16} \mathrm{O}$ fractionation factor (about $+2.6 \%$, i.e., sea ice is more enriched in ${ }^{18} \mathrm{O}$ than the surface seawater; MacDonald et al., 1995; Melling and Moore, 1995). Thus, two tracer parameters, salinity and $\delta^{18} \mathrm{O}$, provide a robust estimate of MW and SIM additions to seawater, the latter of which is characterized by high salinity and $\delta^{18} \mathrm{O}$ values near 0 (Robbins et al., 2013a). In order to further separate seawater sources, a third tracer is necessary, and various semi-conservative parameters have been used (e.g., silicate, phosphate, nutrient ratios, etc.) with variable results (Alkire et al., 2015). In general, these are based on the observation that PW has higher concentrations of nutrients compared to ATW as well as somewhat lower salinity and $\delta^{18} \mathrm{O}$ values.

Using this mass-balance method, fractions of $n$ water sources can be calculated by solving a set of $n$ linear equations, which require $(n-1)$ tracers (i.e., salinity and $\delta^{18} \mathrm{O}$ separate water into 3 sources, one additional tracer is required to separate into four sources). In this study, we utilize only the freshwater source estimates of SIM and MW. Thus, variations between ATW and 
PW sources that depends on the tracer method chosen do not affect the results here. We use the full three-parameter tracers as follows:

$$
\begin{aligned}
& f_{\mathrm{MW}}+f_{\mathrm{SIM}}+f_{\mathrm{PM}}+f_{\mathrm{ATW}}=1 \\
& f_{\mathrm{MW}}\left(S_{\mathrm{MW}}\right)+f_{\mathrm{SIM}}\left(S_{\mathrm{SIM}}\right)+f_{\mathrm{PW}}\left(S_{\mathrm{PW}}\right)+f_{\mathrm{ATW}}\left(S_{\mathrm{ATW}}\right)=S_{\text {observed }} \\
& f_{\mathrm{MW}}\left(\delta^{18} \mathrm{O}_{\mathrm{MW}}\right)+f_{\mathrm{SIM}}\left(\delta^{18} \mathrm{O}_{\mathrm{SIM}}\right)+f_{\mathrm{PW}}\left(\delta^{18} \mathrm{O}_{\mathrm{PW}}\right) \\
& +f_{\mathrm{ATW}}\left(\delta^{18} \mathrm{O}_{\mathrm{ATW}}\right)=\delta^{18} O_{\text {observed }} \\
& f_{\mathrm{MW}}\left(S i_{\mathrm{MW}}\right)+f_{\mathrm{SIM}}\left(S i_{\mathrm{SIM}}\right)+f_{\mathrm{PW}}\left(S i_{\mathrm{PW}}\right) \\
& +f_{\mathrm{ATW}}\left(S i_{\mathrm{ATW}}\right)=S i_{\text {observed }}
\end{aligned}
$$

where, $f, S$, and $S i$ refer to fraction, salinity, and silicate concentration, respectively. The subscripted abbreviations (MW, SIM, PW, and ATW) denote the four water sources. End-member values of the tracers used follow Bauch et al. (1995), YamamotoKawai et al. (2008), and Robbins et al. (2013a): MW: $S=0, \delta^{18} \mathrm{O}$ $=-20 \%$, Si $=10 \mu \mathrm{mol} \mathrm{kg}{ }^{-1}$; SIM: $S=4, \delta^{18} \mathrm{O}=\delta^{18} \mathrm{O}_{\text {surface }}$ $+2.6 \%$, $S i=1 \mu \mathrm{mol} \mathrm{kg}{ }^{-1}$; PW: $S=32.5, \delta^{18} \mathrm{O}=-0.8 \%$, $S i$ $=40 \mu \mathrm{mol} \mathrm{kg}{ }^{-1}$; ATW: $S=34.87, \delta^{18} \mathrm{O}=0.3 \%$, $S i=6 \mu \mathrm{mol}$ $\mathrm{kg}^{-1}$. We follow Bauch et al. (1995) in using dissolved silicate concentration $(\mathrm{Si})$ as the third semi-conservative tracer, but $f_{\mathrm{PW}}$ and $f_{\text {ATW }}$ are not used in this study.

\section{Statistical Analysis}

Statistical differences between variables that were normally or not normally distributed were assessed using independent Samples $T$-test (two-tailed, $\alpha=0.05$ ) or Mann-Whitney $U$ test (two-tailed, $\alpha=0.05$ ), respectively. The normality of data distribution and equality of variances were tested using the Kolmogorov-Smirnov test (two-tailed, $a=0.05$ ) and Levene's test (two-tailed, $a=0.05$ ), respectively. The statistical analyses were performed in SPSS 20.0 (IBM Statistical Package for the Social Sciences Inc.). The significance of least-squares linear regression was determined using the enter approach in SPSS.

\section{Methodological Considerations for DOC and CDOM Measurements and Estimation of Lignin Phenol Concentrations}

A total of 132 DOC reference standards $\left(\mathrm{DOC}_{\mathrm{ref}}\right)$ were measured along with the Arctic samples to evaluate the performance of the DOC analyses (Supplementary Table 1). Concentrations of DOC $_{\text {ref }}$ ranged from 42.2 to $45.9 \mu \mathrm{mol} \mathrm{L}^{-1}$ (avg.: $44.1 \pm 0.9 \mu \mathrm{mol}$ $\left.\mathrm{L}^{-1}\right)$ and were well within the reported range $\left(42-45 \mu \mathrm{mol} \mathrm{L}{ }^{-1}\right)$. Concentrations of $\mathrm{DOC}_{\text {ref }}$ determined during sample analysis for the three cruises showed similar variability and the means were not significantly different ( $T$-test, $p>0.05$ ). Precision of the analysis, represented by coefficient of variation (\%) or standard deviation $\left(\mu \mathrm{mol} \mathrm{L}^{-1}\right)$ of $\mathrm{DOC}_{\text {ref }}$ concentrations, was better than $2.0 \%$ or $1.0 \mu \mathrm{mol} \mathrm{L} \mathrm{L}^{-1}$. These results demonstrate high consistency and reproducibility of the DOC analysis, which facilitates evaluation of the natural variability in DOC concentrations.
Water samples for optical measurements are preferably stored at $4^{\circ} \mathrm{C}$, but logistical issues often require the storage and shipping of frozen samples. Some studies observed substantial changes in CDOM absorbance and fluorescence intensity in freshwater samples following freeze/thaw (Spencer et al., 2007; Fellman et al., 2008; Hudson et al., 2009), while others did not (Spencer et al., 2010; Yamashita et al., 2010). Very few studies have determined the influence of freeze/thaw on CDOM properties in seawater. In this study, comparisons between refrigerated $\left(4^{\circ} \mathrm{C}\right)$ and frozen $\left(-20^{\circ} \mathrm{C}\right)$ seawater samples showed relatively minor differences $(<10 \%)$ in CDOM absorption coefficients at 250-400 nm and in $S_{275-295}$, regardless of sampling locations (Supplementary Figure 1). Freezing appeared to result in some loss of CDOM at lower wavelengths, which was less apparent in samples that were stored unfiltered (Supplementary Figures 1C,D). Paired analyses of 0.7- and $0.2-\mu \mathrm{m}$ filtered samples in each experiment showed similar (mostly $<5 \%$ difference) CDOM absorption coefficients and $S_{275-295}$. These results indicated a minor impact of freezing on CDOM properties in seawater, consistent with previous assessments using seawater samples (Del Castillo and Coble, 2000; Conmy, 2008). In support of this, CDOM absorption coefficients and $S_{275-295}$ measured in the HLY1102 samples in this study were very comparable to those measured in refrigerated $\left(4^{\circ} \mathrm{C}\right)$ samples collected along a similar cruise track during the same period of time (Guéguen et al., 2015).

This study presents detailed distributions of dissolved lignin phenols in the upper Arctic Ocean. To evaluate the validity of the CDOM-derived lignin values, we compared the calculated $\mathrm{TDLP}_{9}$ concentrations to those measured previously using the $\mathrm{CuO}$ oxidation method in similar regions of the Arctic Ocean. Surface $\mathrm{TDLP}_{9}$ concentrations estimated here in the Beaufort Sea, Canada Basin, and Makarov Basin were 222, 2-4, and 9-20 nmol $\mathrm{L}^{-1}$, respectively. These values are similar to those measured in the Mackenzie River Plume (8-30 nmol L $\left.{ }^{-1}\right)$, Beaufort shelf (3-24 nmol L ${ }^{-1}$ ), southern Canada Basin (mostly 2.2-3.0 $\mathrm{nmol} \mathrm{L}^{-1}$ ), and eastern Makarov Basin (10-20 nmol L $\left.{ }^{-1}\right)$ in samples collected between 2002 and 2009 (Fichot et al., 2016; Benner, unpublished; Kaiser et al., in review). These comparisons from similar locations but in different years indicate the CDOM-derived estimates of lignin phenol concentrations are within the ranges of measured values.

\section{RESULTS}

\section{Surface Distributions of Salinity, Meteoric Water, and Sea-Ice Melt}

Surface distributions of salinity, meteoric water, and seaice melt were highly variable in the western Arctic Ocean (Figure 2 and Table 1). The most saline surface waters were observed in the Makarov Basin (30.50 \pm 0.78$)$, whereas the least saline waters were found in the Beaufort Sea (24.81 \pm 3.32). Surface salinities in the Canada Basin (26.54 \pm 2.06) were among the lowest measured in the deep basins. 


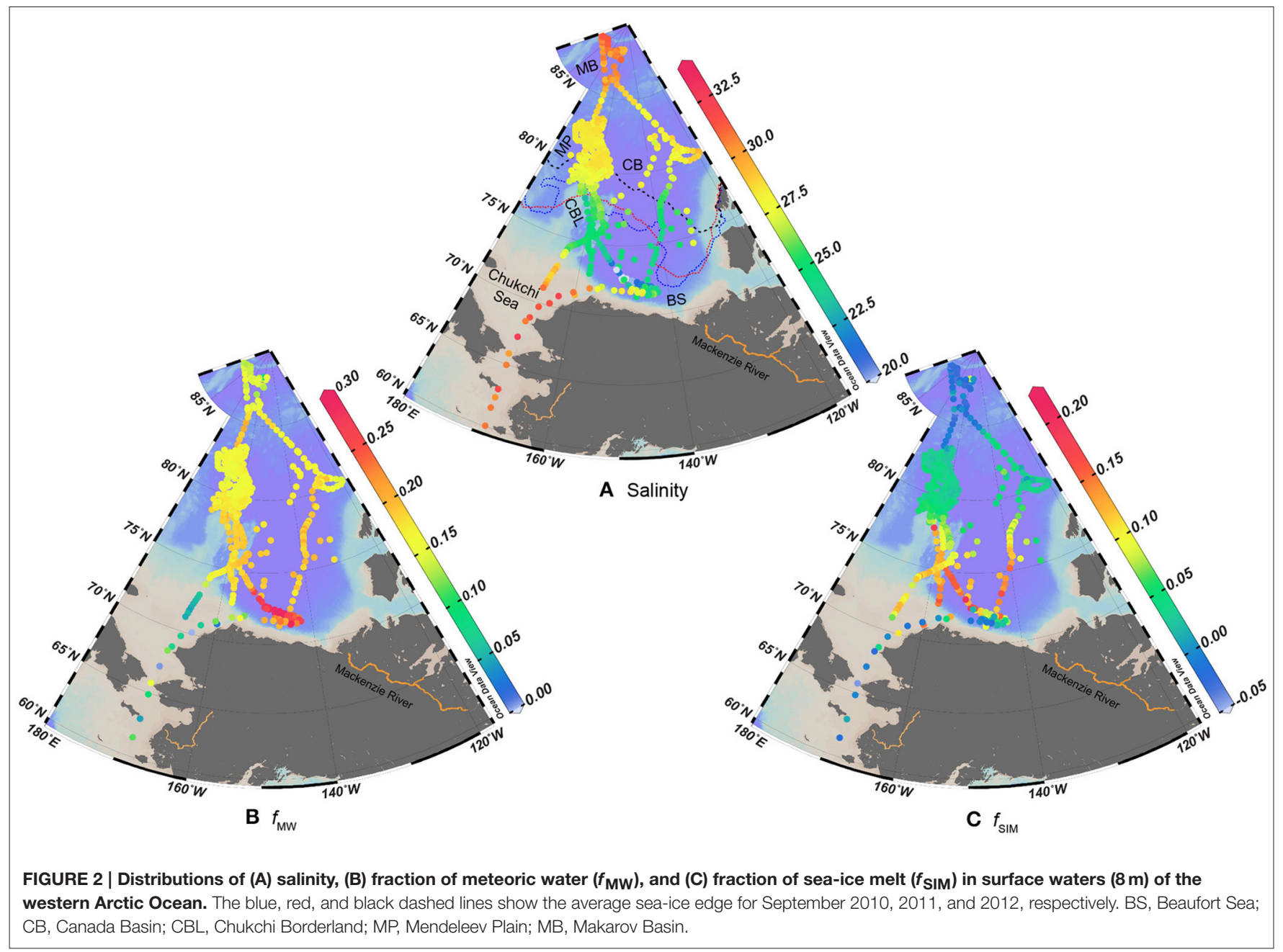

A notable change in surface salinity (by $\sim 3$ ) occurred across the ice front at $\sim 78^{\circ} \mathrm{N}$ in the Canada Basin and near the boundary between the Chukchi Borderland and Mendeleev Plain (Figure 2A).

Fractions of meteoric water $\left(f_{\mathrm{MW}}\right)$ in coastal regions were low in the Bering-Chukchi Seas (0.00-0.15) and high in the Beaufort Sea (0.12-0.32) (Figure 2B and Supplementary Table 2). The $f_{\mathrm{MW}}$ values in the deep basins were relatively constant, averaging $0.18 \pm 0.01,0.17 \pm 0.01$, and $0.15 \pm$ 0.02 in the Canada Basin, Mendeleev Plain, and Makarov Basin, respectively (Supplementary Table 2). Fractions of sea-ice melt $\left(f_{\text {SIM }}\right)$ were highly variable in coastal regions, varying from -0.04 to 0.15 in the Bering-Chukchi Seas and from -0.02 to 0.20 in the Beaufort Sea (Figure 2C and Supplementary Table 2). Negative $f_{\text {SIM }}$ indicate brine rejection from sea-ice formation. The $f_{S I M}$ in the deep basins showed a reverse trend to that of salinity, with elevated values in the southern Canada Basin (0.10-0.20) and negative values in the Makarov Basin (-0.04-0.02). A rapid northward decrease in $f_{\text {SIM }}$ also occurred across the ice front at $\sim 78^{\circ} \mathrm{N}$ (Figure 2C).

\section{Surface Distributions of DOC, CDOM, and Dissolved Lignin Phenols}

The DOC and $\mathrm{TDLP}_{9}$ concentrations and values of $a_{325}$ and $S_{275-295}$ in surface waters of the western Arctic Ocean varied $\sim 3.5$-fold $\left(42-148 \mu \mathrm{mol} \mathrm{L}^{-1}\right), \sim 22$-fold $\left(1-22 \mathrm{nmol} \mathrm{L}^{-1}\right)$, $\sim 13$-fold $\left(0.16-2.06 \mathrm{~m}^{-1}\right)$, and $\sim 1.8$-fold $\left(21.5-38.9 \mu \mathrm{m}^{-1}\right)$, respectively (Figure 3 ). The highest DOC, $a_{325}$, and TDLP , and lowest $S_{275-295}$ were observed in the Beaufort Sea (DOC: $104 \pm$ $23 \mu \mathrm{mol} \mathrm{L}{ }^{-1} ; a_{325}: 1.06 \pm 0.52 \mathrm{~m}^{-1} ; S_{275-295}: 25.8 \pm 2.2 \mu \mathrm{m}^{-1}$; TDLP $_{9}: 10 \pm 6 \mathrm{nmol} \mathrm{L}^{-1}$ ) and the Makarov Basin (DOC: $108 \pm$ $9 \mu \mathrm{mol} \mathrm{L}-1 ; a_{325}: 1.36 \pm 0.18 \mathrm{~m}^{-1} ; S_{275-295}: 22.8 \pm 0.8 \mu \mathrm{m}^{-1}$; TDLP $_{9}: 15 \pm 3 \mathrm{nmol} \mathrm{L}^{-1}$ ) (Table 1). Much lower DOC and TDLP 9 concentrations and $a_{325}$ values and higher $S_{275-295}$ values were found in the Canada Basin (DOC: $69 \pm 6 \mu \mathrm{mol} \mathrm{L}^{-1} ; a_{325}$ : $0.32 \pm 0.07 \mathrm{~m}^{-1} ; S_{275-295}: 31.7 \pm 2.3 \mu \mathrm{m}^{-1}$; TDLP $_{9}: 3 \pm 0.4$ nmol L ${ }^{-1}$ ) and its adjacent areas (Chukchi Borderland, Sever Spur, and Mendeleev Plain). Surface distributions of DOM across the Canada Basin, Chukchi Borderland, and Mendeleev Plain showed no apparent latitudinal trends (Figure 3).

The different DOM signature in the Makarov Basin was due to the influence of the Transpolar Drift. A subset of the dataset 
TABLE 1 | Physicochemical characteristics of various water masses in the western Arctic Ocean.

\begin{tabular}{|c|c|c|c|c|c|c|c|c|c|}
\hline & $\begin{array}{c}\text { Depth } \\
\text { (m) }\end{array}$ & $\begin{array}{l}\text { P. temp. }(\theta) \\
\left({ }^{\circ} \mathrm{C}\right)\end{array}$ & Salinity (S) & $\begin{array}{c}\delta^{18} \mathrm{O} \\
\left(\mathrm{mil}^{-1}\right)\end{array}$ & $\begin{array}{c}\text { DOC } \\
\left(\mu \mathrm{mol} \mathrm{L}^{-1}\right)\end{array}$ & $\begin{array}{c}a_{325} \\
\left(m^{-1}\right)\end{array}$ & $\begin{array}{c}S_{275-295} \\
\left(\mu \mathrm{m}^{-1}\right)\end{array}$ & $\begin{array}{c}\text { TDLP }_{9} \\
\left(\mathrm{nmol} \mathrm{L}^{-1}\right)\end{array}$ & $n$ \\
\hline \multicolumn{10}{|c|}{ POLAR MIXED LAYER $(\mathrm{S}<32)$} \\
\hline BS & $2-80$ & $4.02 \pm 2.53$ & $24.81 \pm 3.32$ & $-4.7 \pm 1.3$ & $104 \pm 23$ & $1.06 \pm 0.52$ & $25.8 \pm 2.2$ & $10 \pm 6$ & 63 \\
\hline $\mathrm{CB}$ & $2-82$ & $-0.69 \pm 1.07$ & $26.54 \pm 2.06$ & $-3.3 \pm 0.4$ & $69 \pm 6$ & $0.32 \pm 0.07$ & $31.7 \pm 2.3$ & $3 \pm 0.4$ & 144 \\
\hline SS & $2-50$ & $-1.50 \pm 0.04$ & $28.45 \pm 0.63$ & $-3.0 \pm 0.3$ & $68 \pm 11$ & $0.29 \pm 0.05$ & $31.7 \pm 1.5$ & $2 \pm 0.4$ & 30 \\
\hline MP & $2-60$ & $-1.29 \pm 0.23$ & $28.40 \pm 0.73$ & $-2.9 \pm 0.3$ & $73 \pm 6$ & $0.35 \pm 0.10$ & $30.5 \pm 1.7$ & $3 \pm 1$ & 197 \\
\hline MB & $2-34$ & $-1.63 \pm 0.04$ & $30.50 \pm 0.78$ & $-2.5 \pm 0.4$ & $108 \pm 9$ & $1.36 \pm 0.18$ & $22.8 \pm 0.8$ & $15 \pm 3$ & 59 \\
\hline \multicolumn{10}{|c|}{ UPPER HALOCLINE $(32<\mathrm{S}<33.9$; MINIMAL $\theta)$} \\
\hline $\mathrm{BS}$ & $137-200$ & $-1.27 \pm 0.23$ & $33.07 \pm 0.51$ & $-1.2 \pm 0.4$ & $64 \pm 2$ & $0.48 \pm 0.03$ & $22.8 \pm 0.3$ & $3 \pm 0.2$ & 3 \\
\hline $\mathrm{CB}$ & 59-202 & $-1.36 \pm 0.13$ & $32.84 \pm 0.59$ & $-1.4 \pm 0.3$ & $65 \pm 3$ & $0.48 \pm 0.03$ & $22.9 \pm 0.7$ & $3 \pm 0.2$ & 29 \\
\hline SS & $76-180$ & $-1.37 \pm 0.13$ & $32.81 \pm 0.72$ & $-1.8 \pm 0.4$ & $68 \pm 4$ & $0.45 \pm 0.04$ & $25.0 \pm 2.0$ & $2 \pm 0.3$ & 4 \\
\hline MP & $100-179$ & $-1.29 \pm 0.21$ & $33.29 \pm 0.76$ & $-0.8 \pm 0.6$ & $65 \pm 5$ & $0.51 \pm 0.10$ & $22.9 \pm 0.7$ & $3 \pm 0.8$ & 4 \\
\hline \multicolumn{10}{|c|}{ LOWER HALOCLINE $\left(33.9<\mathrm{S}<34.7 ; \theta<0^{\circ} \mathrm{C}\right)$} \\
\hline BS & $186-240$ & $-0.75 \pm 0.25$ & $34.18 \pm 0.16$ & $-0.3 \pm 0.1$ & $60 \pm 3$ & $0.39 \pm 0.05$ & $23.9 \pm 0.1$ & $2 \pm 0.3$ & 2 \\
\hline $\mathrm{CB}$ & 198-303 & $-0.74 \pm 0.38$ & $34.25 \pm 0.18$ & $-0.3 \pm 0.2$ & $61 \pm 3$ & $0.40 \pm 0.05$ & $24.6 \pm 0.7$ & $2 \pm 0.3$ & 8 \\
\hline SS & nd & nd & nd & nd & nd & nd & nd & nd & nd \\
\hline MP & 206 & -0.68 & 34.30 & 0.00 & 62 & 0.40 & 23.7 & 2 & 1 \\
\hline \multicolumn{10}{|c|}{ HALOCLINE WATER $\left(32.5<\mathrm{S}<34.5 ; \theta<0^{\circ} \mathrm{C}\right)$} \\
\hline MB & $50-150$ & $-1.25 \pm 0.60$ & $33.72 \pm 0.68$ & $-0.6 \pm 0.6$ & $70 \pm 14$ & $0.58 \pm 0.29$ & $23.7 \pm 1.5$ & $4 \pm 4$ & 10 \\
\hline \multicolumn{10}{|c|}{ ATLANTIC LAYER $\left(34.7<\mathrm{S}<34.9 ; \theta>0^{\circ} \mathrm{C}\right)$} \\
\hline BS & $305-801$ & $0.49 \pm 0.17$ & $34.81 \pm 0.05$ & $0.2 \pm 0.2$ & $53 \pm 3$ & $0.22 \pm 0.05$ & $27.6 \pm 1.1$ & nd & 7 \\
\hline $\mathrm{CB}$ & 298-999 & $0.41 \pm 0.23$ & $34.83 \pm 0.06$ & $0.2 \pm 0.1$ & $53 \pm 3$ & $0.20 \pm 0.03$ & $27.7 \pm 0.7$ & nd & 33 \\
\hline SS & $325-500$ & $0.49 \pm 0.01$ & $34.81 \pm 0.06$ & $0.4 \pm 0.1$ & $52 \pm 0$ & $0.16 \pm 0.00$ & $30.7 \pm 1.6$ & nd & 2 \\
\hline MP & 299-800 & $0.53 \pm 0.33$ & $34.81 \pm 0.05$ & $0.5 \pm 0.1$ & $53 \pm 1$ & $0.20 \pm 0.02$ & $28.0 \pm 0.5$ & nd & 6 \\
\hline MB & $200-813$ & $0.53 \pm 0.37$ & $34.79 \pm 0.12$ & $0.2 \pm 0.1$ & $54 \pm 4$ & $0.20 \pm 0.02$ & $28.4 \pm 1.4$ & nd & 14 \\
\hline \multicolumn{10}{|c|}{ ARCTIC DEEP WATER $\left(1000-2500 \mathrm{M} ; \theta<0^{\circ} \mathrm{C}\right)$} \\
\hline BS & $1001-1400$ & $-0.21 \pm 0.19$ & $34.90 \pm 0.02$ & $0.3 \pm 0.1$ & $52 \pm 0$ & $0.21 \pm 0.01$ & $27.4 \pm 1.6$ & nd & 2 \\
\hline $\mathrm{CB}$ & 1000-2542 & $-0.36 \pm 0.18$ & $34.92 \pm 0.02$ & $0.3 \pm 0.1$ & $49 \pm 3$ & $0.17 \pm 0.02$ & $27.1 \pm 1.1$ & nd & 18 \\
\hline SS & 1500-2499 & $-0.45 \pm 0.08$ & $34.94 \pm 0.02$ & $0.5 \pm 0.1$ & $45 \pm 4$ & $0.12 \pm 0.00$ & $32.5 \pm 1.7$ & nd & 2 \\
\hline MP & 1000-2001 & $-0.32 \pm 0.21$ & $34.90 \pm 0.04$ & $0.5 \pm 0.1$ & $48 \pm 3$ & $0.16 \pm 0.00$ & $27.9 \pm 0.6$ & nd & 5 \\
\hline MB & 900-2500 & $-0.38 \pm 0.16$ & $34.92 \pm 0.03$ & $0.3 \pm 0.1$ & $49 \pm 4$ & $0.17 \pm 0.02$ & $27.5 \pm 0.9$ & nd & 10 \\
\hline \multicolumn{10}{|c|}{ ARCTIC BOTTOM WATER (>2500 M; CONSTANT IN S AND $\theta$ ) } \\
\hline BS & nd & nd & nd & nd & nd & nd & nd & nd & nd \\
\hline $\mathrm{CB}$ & $3000-3824$ & $-0.51 \pm 0.01$ & $34.95 \pm 0.01$ & $0.3 \pm 0.1$ & $46 \pm 1$ & $0.16 \pm 0.02$ & $25.8 \pm 1.2$ & nd & 7 \\
\hline SS & 3059 & -0.51 & 34.96 & 0.4 & 49 & 0.14 & 30.0 & nd & 1 \\
\hline MP & 2712-2960 & $-0.50 \pm 0.01$ & $34.94 \pm 0.00$ & $0.5 \pm 0.0$ & $44 \pm 1$ & $0.14 \pm 0.01$ & $26.8 \pm 0.1$ & nd & 2 \\
\hline MB & 2860-3350 & $-0.52 \pm 0.01$ & $34.95 \pm 0.00$ & $0.4 \pm 0.1$ & $46 \pm 2$ & $0.16 \pm 0.00$ & $26.6 \pm 0.7$ & nd & 3 \\
\hline
\end{tabular}

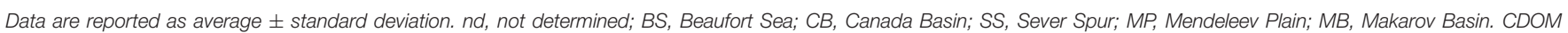
absorption coefficients at other wavelengths are provided in Supplementary Table 4.

was extracted to characterize concentrations and compositions of DOM in the Transpolar Drift. Data $(n=52 ; 8 \mathrm{~m})$ collected in regions north of $\sim 83^{\circ} \mathrm{N}$, including the Makarov Basin, Mendeleev Ridge, and Alpha Ridge, were ranked by each of four DOM parameters (DOC, $a_{325}, \mathrm{TDLP}_{9}, S_{275-295}$ ), and the data within the upper $50 \%$ of every parameter (lower $50 \%$ in the case of $\left.S_{275-295}\right)$ were averaged $(n=19)$ to represent the concentration and composition of DOM in the Transpolar Drift. Values for DOC $\left(114 \pm 5 \mu \mathrm{mol} \mathrm{L}^{-1}\right), a_{325}\left(1.48 \pm 0.09 \mathrm{~m}^{-1}\right)$, $S_{275-295}\left(22.4 \pm 0.3 \mu \mathrm{m}^{-1}\right)$, and $\mathrm{TDLP}_{9}\left(17 \pm 1 \mathrm{nmol} \mathrm{L}^{-1}\right)$ in the Transpolar Drift indicated the highest concentrations of terrigenous DOM observed in this study (Supplementary Table 2).

\section{Influence of Meteoric Water and Sea-Ice Melt on Surface Salinity and DOM}

Regression analyses were performed to investigate the influence of meteoric water and sea-ice melt on salinity, DOC, CDOM, and dissolved lignin phenols in surface waters of the western Arctic Ocean (Figures 4-6 and Supplementary Table 3). Data from the Canada Basin, Chukchi Borderland, and Sever Spur were combined (denoted as Canada Basin*) in the regression analysis given their geographic proximity and similar distributions of DOM. It is interesting to note that the geographic connections among the deep basins (Canada Basin*, Mendeleev Plain, and Makarov Basin) were 


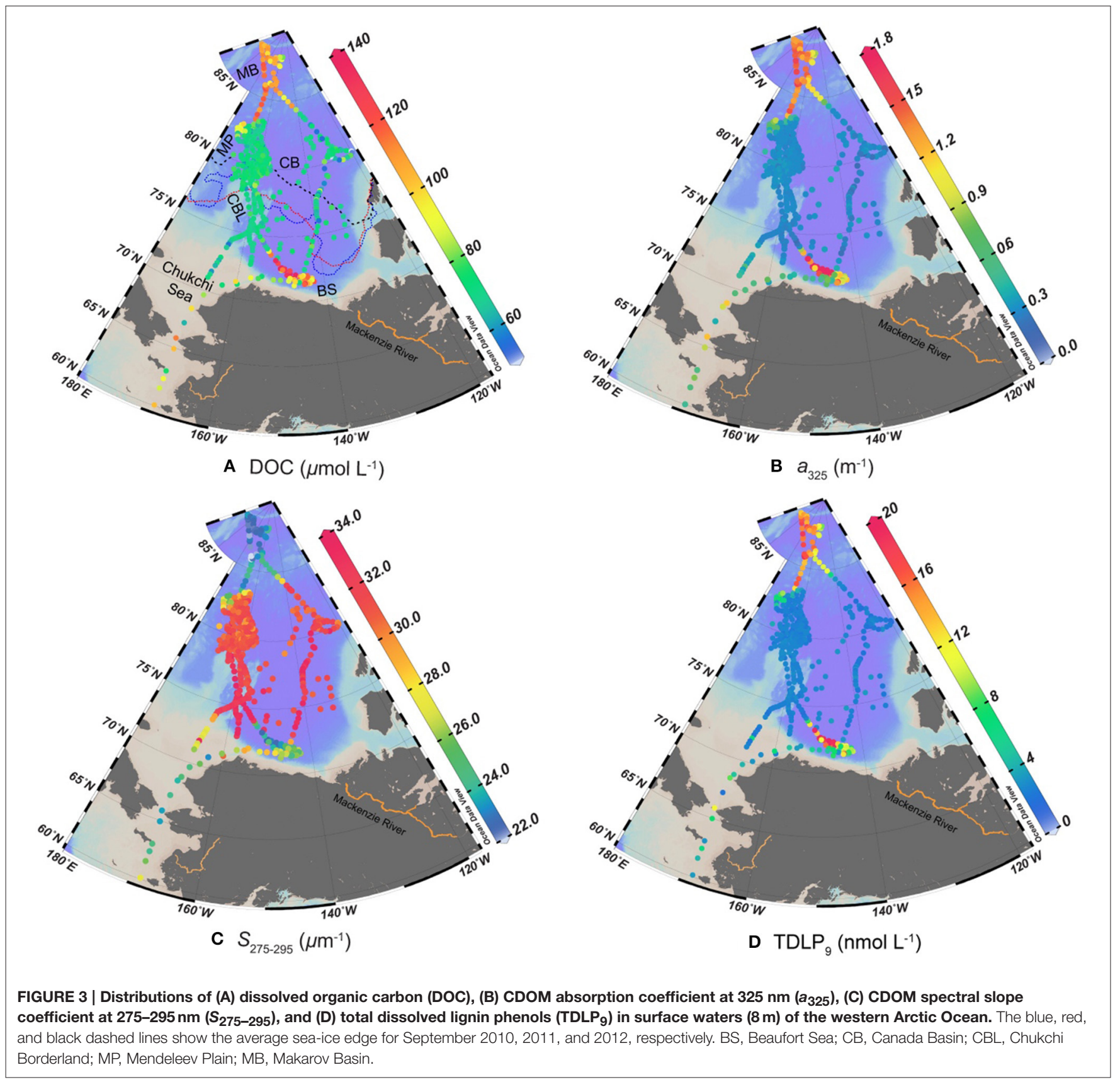

revealed by the continuum of salinity and DOM distributions (Figures 4-6).

Salinity in surface waters was influenced to varying extents by meteoric water and sea-ice melt inputs (Figure 4 and Supplementary Table 3). Meteoric water showed a moderate dilution effect on the surface salinity in the Beaufort Sea $\left(R^{2}=\right.$ 0.630, $p<0.001)$, Mendeleev Plain $\left(R^{2}=0.461, p<0.001\right)$, and Makarov Basin $\left(R^{2}=0.613, p<0.001\right.$; Figure 4A). This dilution effect was much weaker in Canada Basin* $\left(R^{2}=0.287\right)$ and was not apparent in the Bering-Chukchi Seas $\left(R^{2}=0.005\right)$. In comparison, sea-ice melt showed a moderate to strong dilution influence on the surface salinity in all regions $\left(R^{2}=0.420-0.920\right.$, $p<0.001$ ) except the Makarov Basin (Figure 4B). The influence of sea-ice melt was most pronounced in the Canada Basin* $\left(R^{2}=\right.$ $0.920, p<0.001)$ and it gradually diminished in the Mendeleev Plain $\left(R^{2}=0.420, p<0.001\right)$ and Makarov Basin $\left(R^{2}=0.273, p\right.$ $<0.001)$.

Relationships between meteoric water and DOM parameters were spatially variable (Figure 5 and Supplementary Table 3), with moderate to strong relationships in coastal regions (BeringChukchi Seas and Beaufort Sea: $R^{2}=0.595-0.764, p<0.001$ ) and weak or no relationships in the deep basins (Canada Basin*, Mendeleev Plain, and Makarov Basin: $\left.R^{2}=0.01-0.25\right)$. Increasing meteoric water in the Bering-Chukchi and Beaufort 

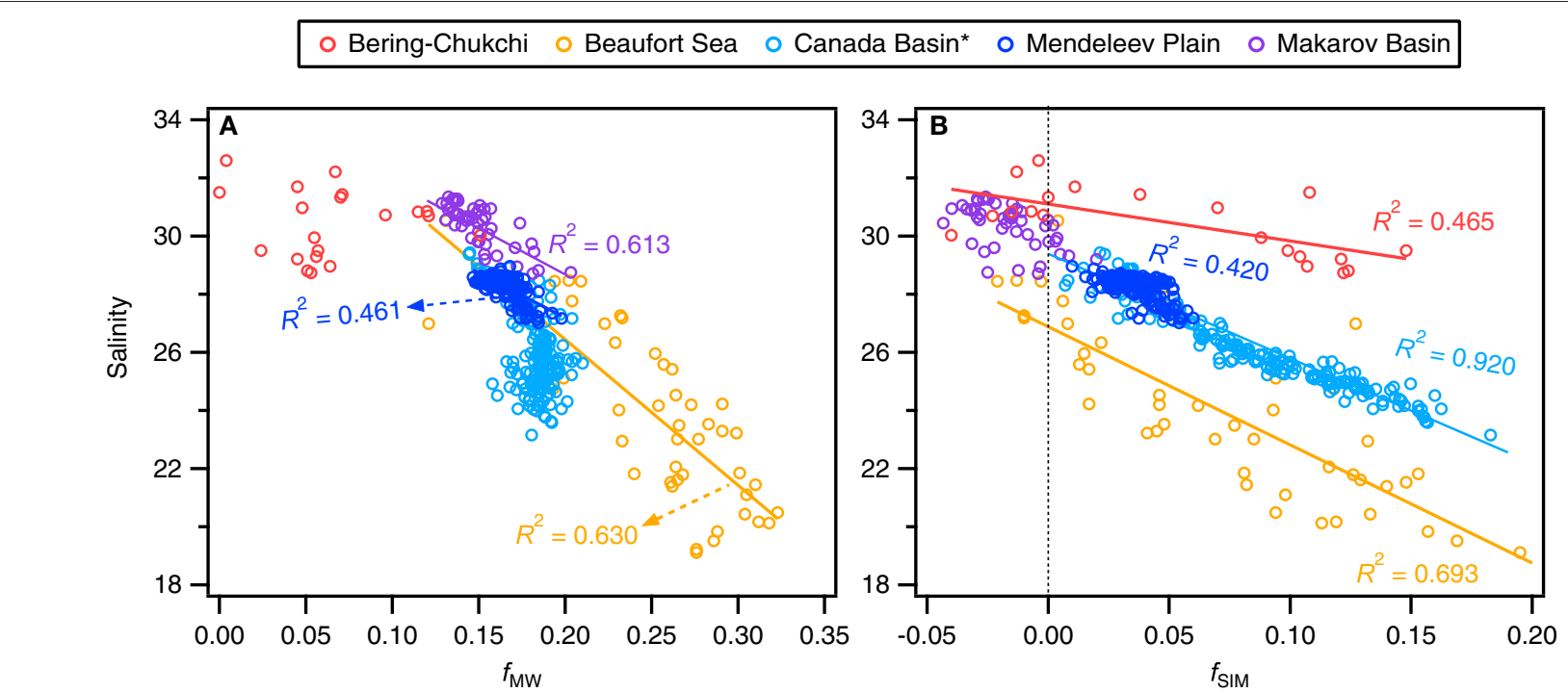

FIGURE 4 | Relationships between salinity and $(A)$ meteoric water fraction $\left(f_{M W}\right)$ and $(B)$ sea-ice melt fraction $\left(f_{\text {SIM }}\right)$ in surface waters $(8 \mathrm{~m})$ of the western Arctic Ocean. Data in the Canada Basin, Chukchi Borderland, and Sever Spur were combined (denoted as Canada Basin*) in the regression analysis.
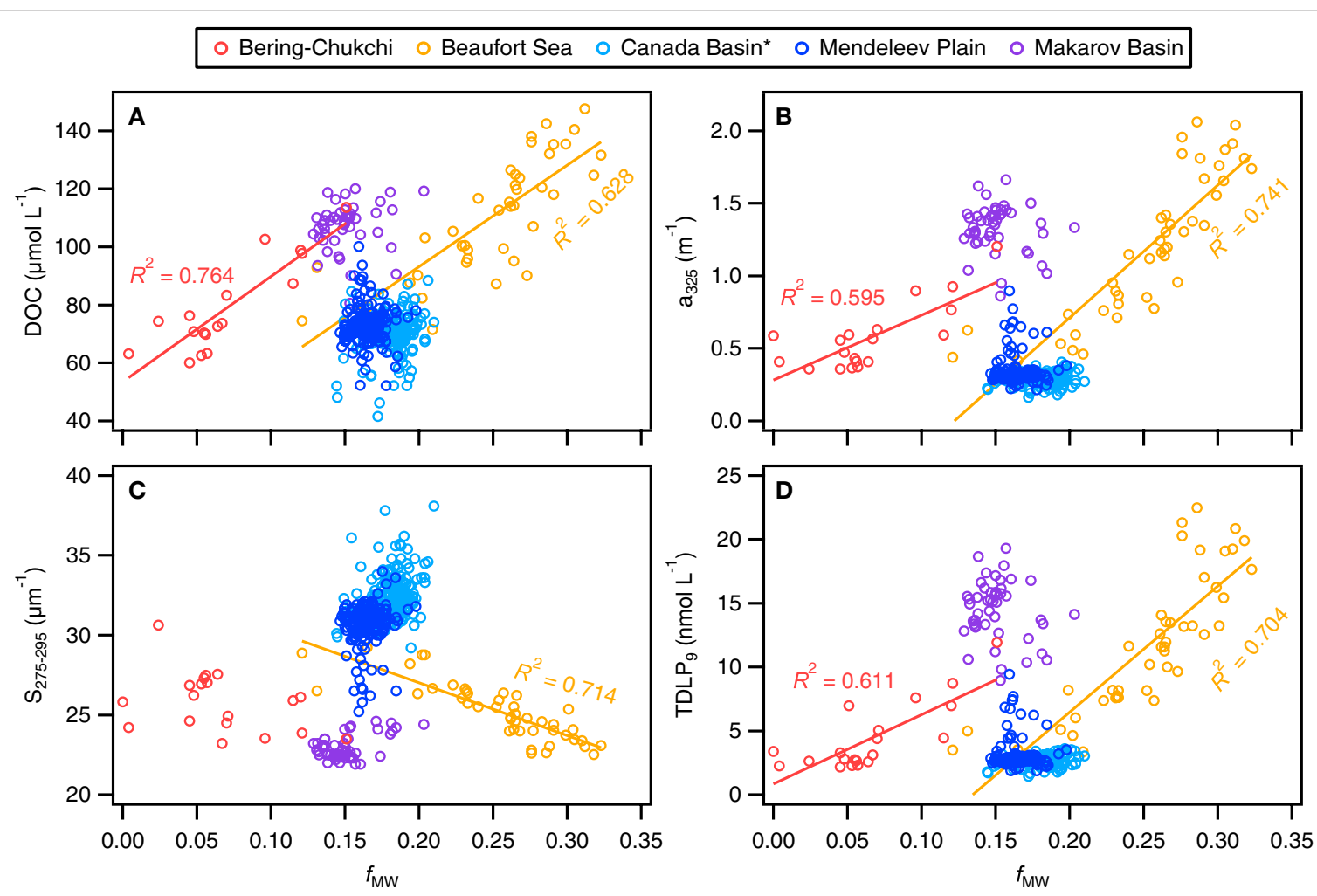

FIGURE 5 | Relationships between meteoric water fraction $\left(f_{M W}\right)$ and $(A)$ dissolved organic carbon (DOC), (B) CDOM absorption coefficient at 325 nm $\left(a_{325}\right),(C)$ CDOM spectral slope coefficient at $275-295 \mathrm{~nm}\left(S_{275-295}\right)$, and $(D)$ total dissolved lignin phenols (TDLP $)$ in surface waters $(8 \mathrm{~m})$ of the western Arctic Ocean. Data in the Canada Basin, Chukchi Borderland, and Sever Spur were combined (denoted as Canada Basin*) in the regression analysis.

Seas resulted in higher concentrations of DOC, $a_{325}$, and TDLP, and lower $S_{275-295}$. One exception occurred in the BeringChukchi Seas, where $S_{275-295}$ values showed little variation with meteoric water (Figure 5C).
The influence of sea-ice melt on DOM was also variable among regions (Figure 6 and Supplementary Table 3). In the Bering-Chukchi Seas, increasing sea-ice melt resulted in decreasing DOC concentrations $\left(R^{2}=0.501, p<0.001\right), a_{325}$ 

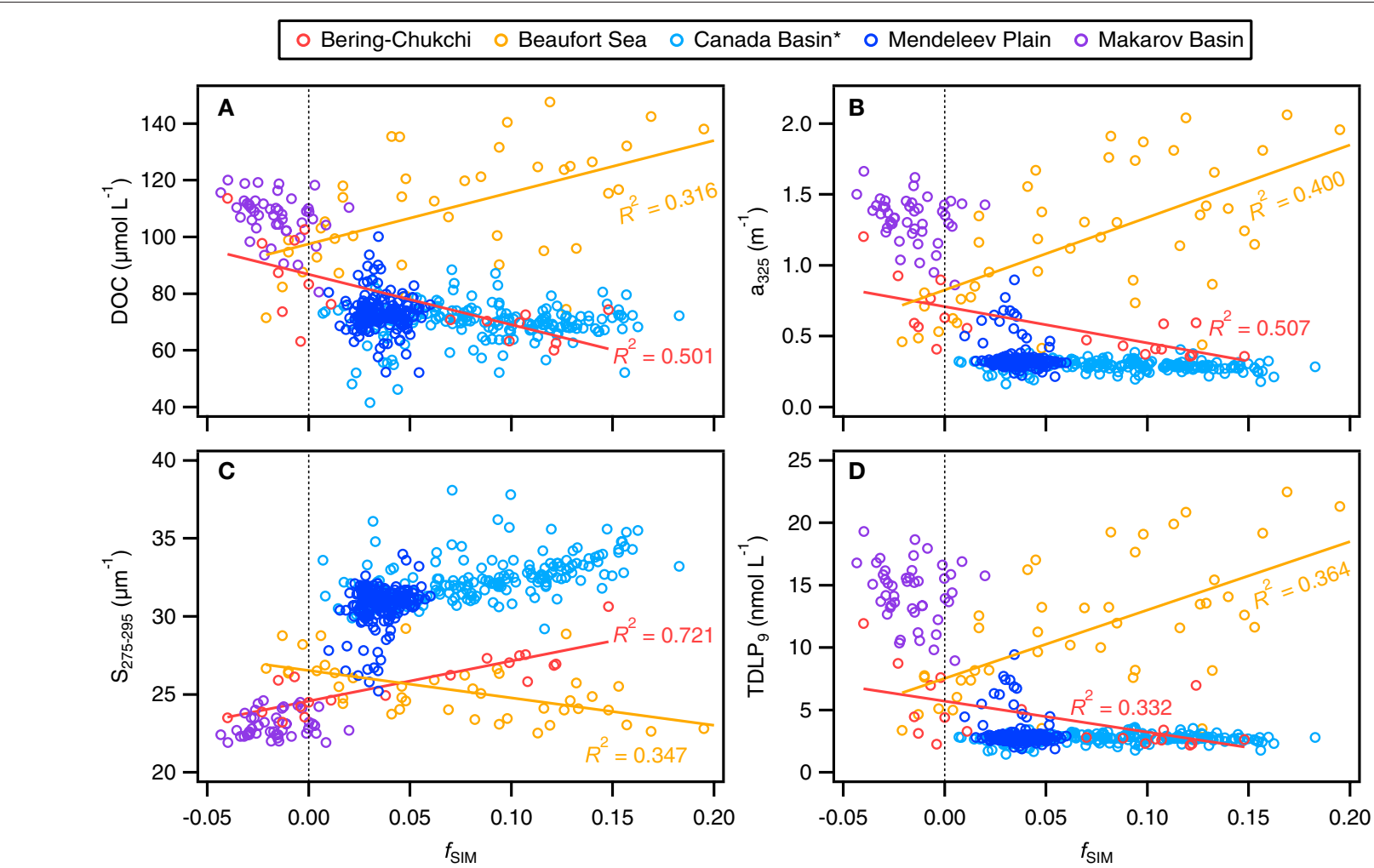

FIGURE 6 | Relationships between sea-ice melt fraction ( $\left.f_{\text {SIM }}\right)$ and (A) dissolved organic carbon (DOC), (B) CDOM absorption coefficient at $325 \mathrm{~nm}$ $\left(a_{325}\right)$, (C) CDOM spectral slope coefficient at $275-295 \mathrm{~nm}\left(S_{275-295}\right)$, and (D) total dissolved lignin phenols (TDLP $)$ in surface waters $(8 \mathrm{~m})$ of the western Arctic Ocean. Data in the Canada Basin, Chukchi Borderland, and Sever Spur were combined (denoted as Canada Basin*) in the regression analysis.

values $\left(R^{2}=0.507, p<0.001\right)$, TDLP 9 concentrations $\left(R^{2}=\right.$ $0.332, p<0.05)$, and increasing $S_{275-295}$ values $\left(R^{2}=0.721, p\right.$ $<0.001)$. By contrast, increasing sea-ice melt in the Beaufort Sea led to higher DOC concentrations $\left(R^{2}=0.316, p<0.001\right)$, $a_{325}$ values $\left(R^{2}=0.400, p<0.001\right)$, TDLP 9 concentrations $\left(R^{2}\right.$ $=0.364, p<0.001)$, and lower $S_{275-295}$ values $\left(R^{2}=0.347\right.$, $p<0.001)$. Sea-ice melt in the deep basins showed weak or no relationships with DOM parameters $\left(R^{2}=0-0.12\right)$. One exception was found in $S_{275-295}$, which increased significantly with sea-ice melt in the Canada Basins* $\left(R^{2}=0.237, p<0.001\right.$; Figure 6C).

\section{Water Masses in the Western Arctic Ocean}

Water masses in the Arctic Ocean are distinguishable by their physical and chemical properties (Jones et al., 1995; Rudels et al., 1996; Shimada et al., 2005; Rudels, 2009). In this study, six water masses were identified in the western Arctic Ocean based primarily on salinity and potential temperature (Table 1). The polar mixed layer (PML) occupied the upper $30-80 \mathrm{~m}$ of the water column (shallower in the Makarov Basin) and had relatively low salinity $(<32.0)$. The upper halocline $(\mathrm{UH})$ resided below the PML at depths of $80-200 \mathrm{~m}$ and centered at a salinity of 33.1. The UH waters had higher concentrations of brine (i.e., negative $f_{\text {SIM }}$ values) and nutrients (e.g., silicate) and lower temperatures than ambient waters (Figure 7 and Table 1). These characteristics were prominent in the Beaufort Sea, Canada Basin, and Mendeleev Plain but were absent in the Makarov Basin. The lower halocline (LH) was found at depths of 200$300 \mathrm{~m}$ with higher salinities ranging from 33.9 to 34.7. Upper and lower haloclines were not distinguishable in the Makarov Basin, where a cold halocline $\left(\theta<0^{\circ} \mathrm{C}\right)$ was present at depths of $50-150 \mathrm{~m}$ with salinities ranging from 32.5 to 34.5 (Steele and Boyd, 1998; Rudels et al., 2004; Bauch et al., 2016). Below the halocline waters, the denser $(34.7<\mathrm{S}<34.9)$ and warmer $\left(\theta>0^{\circ} \mathrm{C}\right)$ Atlantic waters were identified at depths down to $\sim 1000 \mathrm{~m}$. Below the Atlantic waters are the cold $\left(\theta<0^{\circ} \mathrm{C}\right)$ Arctic deep (1000-2500 m) and bottom (>2500 m) waters. Salinities increased and temperatures decreased with depth in Arctic deep waters and they became relatively constant in Arctic bottom waters (Table 1).

\section{Vertical Distributions of DOC and CDOM in the Deep Basins}

Concentrations of DOC varied $\sim 2$ to 3 -fold with depth in the basins, ranging from 44 to $88 \mu \mathrm{mol} \mathrm{L}^{-1}$ and from 42 to $100 \mu \mathrm{mol} \mathrm{L}^{-1}$ in the Canada Basin and adjacent areas (Sever Spur and Mendeleev Plain) and from 43 to $129 \mu \mathrm{mol} \mathrm{L}^{-1}$ in the Makarov Basin (Figure 8 and Table 1). Depth distributions of DOC concentrations in the Canada Basin and adjacent areas were very similar and showed no apparent latitudinal trends 


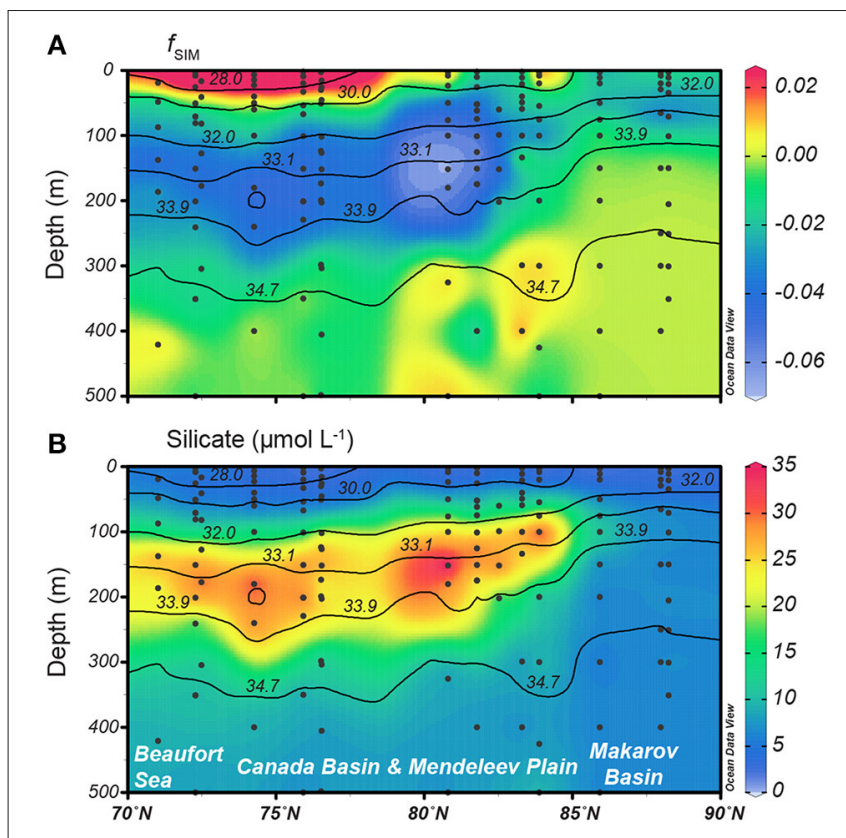

FIGURE 7 | Sections $\left(70^{\circ} \mathrm{N}-88^{\circ} \mathrm{N}\right)$ of $(\mathrm{A})$ sea-ice melt fraction $\left(f_{\text {SIM }}\right)$ and (B) silicate $\left(\mathrm{SiO}_{4}\right)$ in the upper $500 \mathrm{~m}$ of the Canada and Makarov

Basins. Solid dots represent sampling sites and solid lines depict the contour lines of salinity.

(Figure 8A). Comparisons between the Canada and Makarov Basins revealed different distributions of DOC concentrations in the upper $300 \mathrm{~m}$ of the water column (Figure 8C). In the Canada Basin, DOC concentrations were slightly elevated in the PML (69 $\pm 6 \mu \mathrm{mol} \mathrm{L}^{-1}$ ) and gradually decreased with increasing depth from the halocline (UH: $65 \pm 3 \mu \mathrm{mol} \mathrm{L}^{-1}$; LH: $61 \pm 3 \mu \mathrm{mol}$ $\left.\mathrm{L}^{-1}\right)$ to the Atlantic layer $\left(53 \pm 3 \mu \mathrm{mol} \mathrm{L}^{-1}\right)$ and to Arctic deep $\left(49 \pm 3 \mu \mathrm{mol} \mathrm{L}^{-1}\right)$ and bottom waters $\left(46 \pm 1 \mu \mathrm{mol} \mathrm{L}{ }^{-1}\right)$. In comparison, concentrations of DOC in the Makarov Basin were greatly elevated in the PML $\left(108 \pm 9 \mu \mathrm{mol} \mathrm{L}^{-1}\right)$ and decreased rapidly and conservatively with salinity $\left(R^{2}=0.78, p<0.001, n\right.$ $=10)$ in the halocline layer $\left(70 \pm 14 \mu \mathrm{mol} \mathrm{L}^{-1}\right.$; Figure 8B). The DOC concentrations in the Atlantic layer $\left(54 \pm 4 \mu \mathrm{mol} \mathrm{L}^{-1}\right)$ and the Arctic deep $\left(49 \pm 4 \mu \mathrm{mol} \mathrm{L}{ }^{-1}\right)$ and bottom waters $(46 \pm 2$ $\left.\mu \mathrm{mol} \mathrm{L}{ }^{-1}\right)$ in the Makarov Basin were very similar to those in the Canada Basin (Mann-Whitney $U$-Test, $p>0.05$; Figure 8C and Table 1).

A striking gradient in DOC concentrations was observed in deep waters of the Canada and Makarov Basins (Figures 8C, 9).

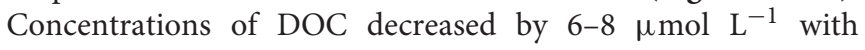
increasing water mass age at depths of $\sim 1000-2500 \mathrm{~m}$ (Figure 9 and Table 1). Declines in DOC concentrations were significantly related to increases in salinity and apparent oxygen utilization (AOU) $(\mathrm{DOC}=3434-96.85 \times$ salinity $-0.05 \times$ AOU: $\left.R^{2}=0.62, p<0.001\right)$ and inorganic nitrogen and silicate concentrations $\left(R^{2}=0.50-0.70, p\right.$ $<0.001)$. Concentrations of DOC in Arctic bottom water $(>2500 \mathrm{~m})$ were less variable with depth, consistent with the relatively constant physical properties in these waters (Table 1).
The $a_{325}$ values in the deep basins were much more variable than DOC concentrations, varying $\sim 4$-fold $\left(0.13-0.55 \mathrm{~m}^{-1}\right)$ in the Canada Basin and $\sim 13$-fold $\left(0.13-1.70 \mathrm{~m}^{-1}\right)$ in the Makarov Basin (Figure 10 and Table 1). As observed with DOC, distributions of $a_{325}$ were quite different between the two basins in the upper $300 \mathrm{~m}$ of the water column (Figure 10C). The $a_{325}$ in the Canada Basin was relatively low in the PML $(0.32 \pm 0.07$ $\mathrm{m}^{-1}$ ) and showed a maximum of $0.48 \pm 0.03 \mathrm{~m}^{-1}$ in the $\mathrm{UH}$, below which $a_{325}$ decreased conservatively with salinity in the $\mathrm{LH}$ and upper Atlantic layer (200-300 m: $R^{2}=0.933, p<0.001, n$ $=18$; Figure 10A). In comparison, $a_{325}$ in the Makarov Basin reached a maximum of $1.36 \pm 0.18 \mathrm{~m}^{-1}$ in the PML, and the values decreased rapidly and conservatively with salinity in the halocline layer $\left(0.58 \pm 0.29 \mathrm{~m}^{-1} ; R^{2}=0.92, p<0.001, n=\right.$ 10; Figure 10B). The $a_{325}$ below $300 \mathrm{~m}$ showed similar values and distributions between the two basins (Mann-Whitney $U$ Test, $p>0.1$ ). Deep-sea gradients in $a_{325}$ were observed and they showed opposite trends between the Arctic deep water and Arctic bottom water (Figure 10C). The $a_{325}$ in Arctic deep water decreased substantially with depth in the Canada Basin (from 0.20 to $0.15 \mathrm{~m}^{-1}$ ) and Makarov Basin (from 0.19 to $0.13 \mathrm{~m}^{-1}$ ), a feature similar to the decline in DOC concentrations. By contrast, $a_{325}$ values in Arctic bottom water at all eight stations were significantly elevated (by 10-20\%) toward the seafloor (T-Test, $p<0.05$; Figure 10C).

The $S_{275-295}$ ranged from 21.3 to $38.1 \mu \mathrm{m}^{-1}$ with depth in the Canada Basin and from 21.5 to $31.3{\mu \mathrm{m}^{-1}}$ in the Makarov Basin (Figure 11 and Table 1). The $S_{275-295}$ in the Canada Basin was elevated in the PML $\left(31.7 \pm 2.3 \mu \mathrm{m}^{-1}\right)$ and decreased rapidly to a minimum of $22.9 \pm 0.7 \mu \mathrm{m}^{-1}$ in the $\mathrm{UH}$, below which $S_{275-295}$ increased with depth and the values varied mostly between 25 and $28 \mathrm{\mu m}^{-1}$ (Figure 11A). In the Makarov Basin, $S_{275-295}$ values were low in the PML $\left(22.8 \pm 0.8 \mu \mathrm{m}^{-1}\right)$ and increased with depth in the halocline $\left(23.7 \pm 1.5 \mu \mathrm{m}^{-1}\right.$; Figure 11B). The $S_{275-295}$ values below $300 \mathrm{~m}$ were comparable to those at matching depths in the Canada Basin (Mann-Whitney $U$-Test, $p>0.05$; Figure 11C). Lower $S_{275-295}$ values were observed near the seafloor of the Canada and Makarov Basins.

\section{Relationships between DOC and CDOM}

These data provided an opportunity to evaluate relationships between DOC concentrations and CDOM absorption in the Arctic Ocean. A total of 755 paired measurements in this study revealed a strong relationship between DOC concentrations and CDOM absorption (e.g., $a_{325}: R^{2}=0.77-0.87, p<$ 0.001; Supplementary Figure 2). This feature is absent in the Pacific, Atlantic, and Indian Oceans (Nelson et al., 2010), and it allows the developments of empirical models to retrieve DOC concentrations from CDOM measurements in the Arctic Ocean. By re-parameterizing a previously developed multi-linear regression model (Fichot and Benner, 2011) using the present data set, two sub-models separated by a cutoff value of $a_{275}=$ $1.42 \mathrm{~m}^{-1}$ (i.e., the median) were established.

When $a_{275} \leq 1.42 \mathrm{~m}^{-1}$,

$$
\begin{aligned}
\ln [\mathrm{DOC}]= & 3.881 \pm 0.036+0.763 \pm 0.057 \times \ln \left(a_{275}\right) \\
& -0.375 \pm 0.061 \times \ln \left(a_{295}\right)
\end{aligned}
$$




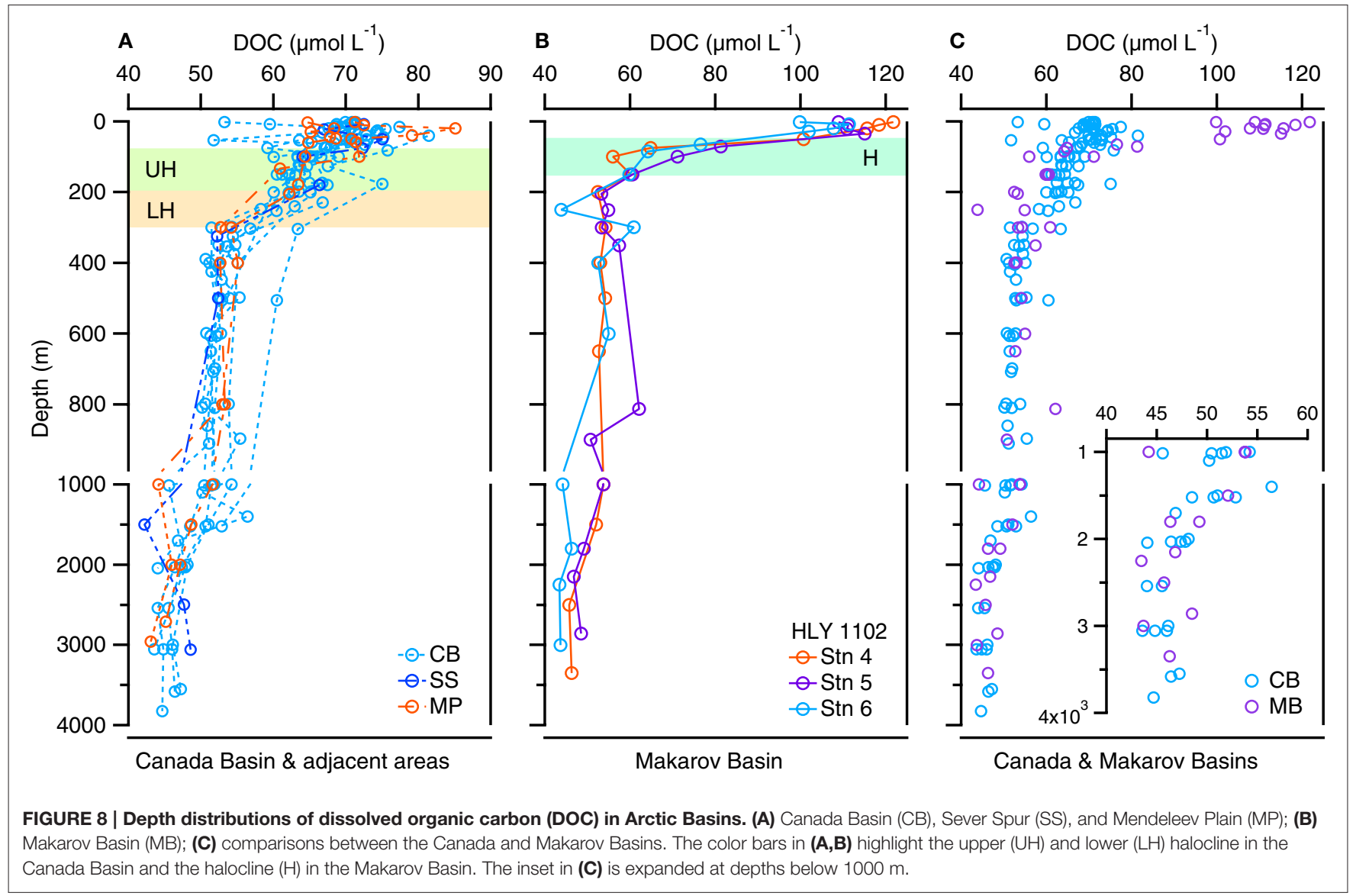

When $a_{275}>1.42 \mathrm{~m}^{-1}$,

$$
\begin{aligned}
\ln [\mathrm{DOC}]= & 3.643 \pm 0.032+1.223 \pm 0.055 \times \ln \left(a_{275}\right) \\
& -0.701 \pm 0.049 \times \ln \left(a_{295}\right)
\end{aligned}
$$

The standard error of each regression coefficient is given in the equations. The estimated concentrations of DOC exhibited a fairly strong relationship with the measured values $\left(R^{2}=0.951\right.$, $p<0.001$; Figure 12). The error associated with the retrieval of DOC concentration using this approach was generally within $15 \%$. The broad range of DOC and CDOM values included in the data suggests the models could be applicable to other regions of the Arctic Ocean.

\section{DISCUSSION}

\section{Abundance and Distribution of DOM in Surface Waters}

This study demonstrated that the abundance and distribution of DOM in polar surface waters were very heterogeneous and strongly linked to hydrological conditions. High concentrations of DOC and lignin phenols, high values of $a_{325}$, and low values of $S_{275-295}$ were observed in surface waters of the Beaufort Sea. These concentrations and values were significantly correlated to $f_{\mathrm{MW}}$, reflecting the influence of the Mackenzie River. Elevated
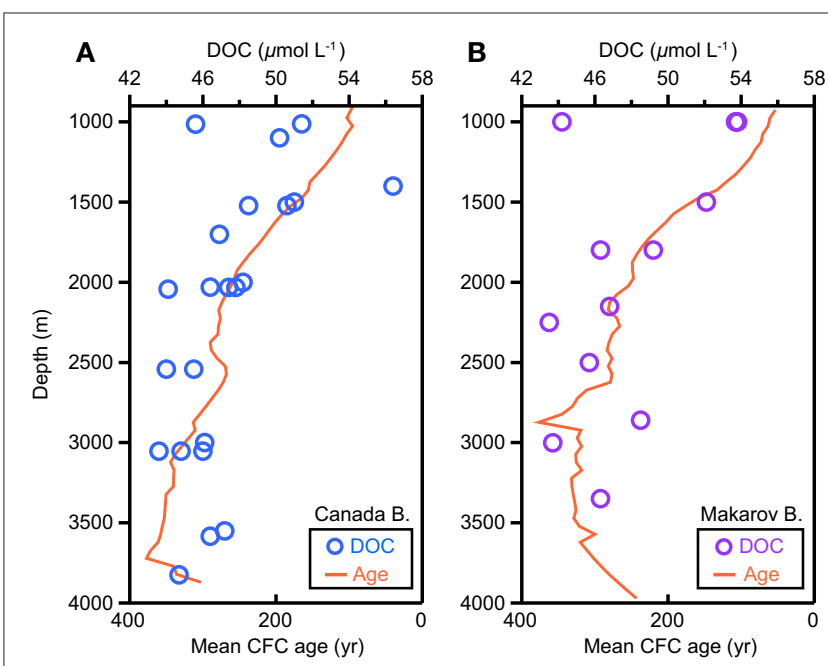

FIGURE 9 | Depth distributions of dissolved organic carbon (DOC) and mean chlorofluorocarbon (CFC) age in the Arctic deep and bottom waters: (A) Canada Basin and (B) Makarov Basin. Data of CFC age were obtained from Tanhua et al. (2009).

DOC $\left(>100 \mu \mathrm{mol} \mathrm{L} \mathrm{L}^{-1}\right)$ and lignin phenol concentrations $\left(>10 \mathrm{nmol} \mathrm{L}^{-1}\right)$ were present in the northwest region of the Beaufort Sea, indicating the transport of riverine DOM to surface 


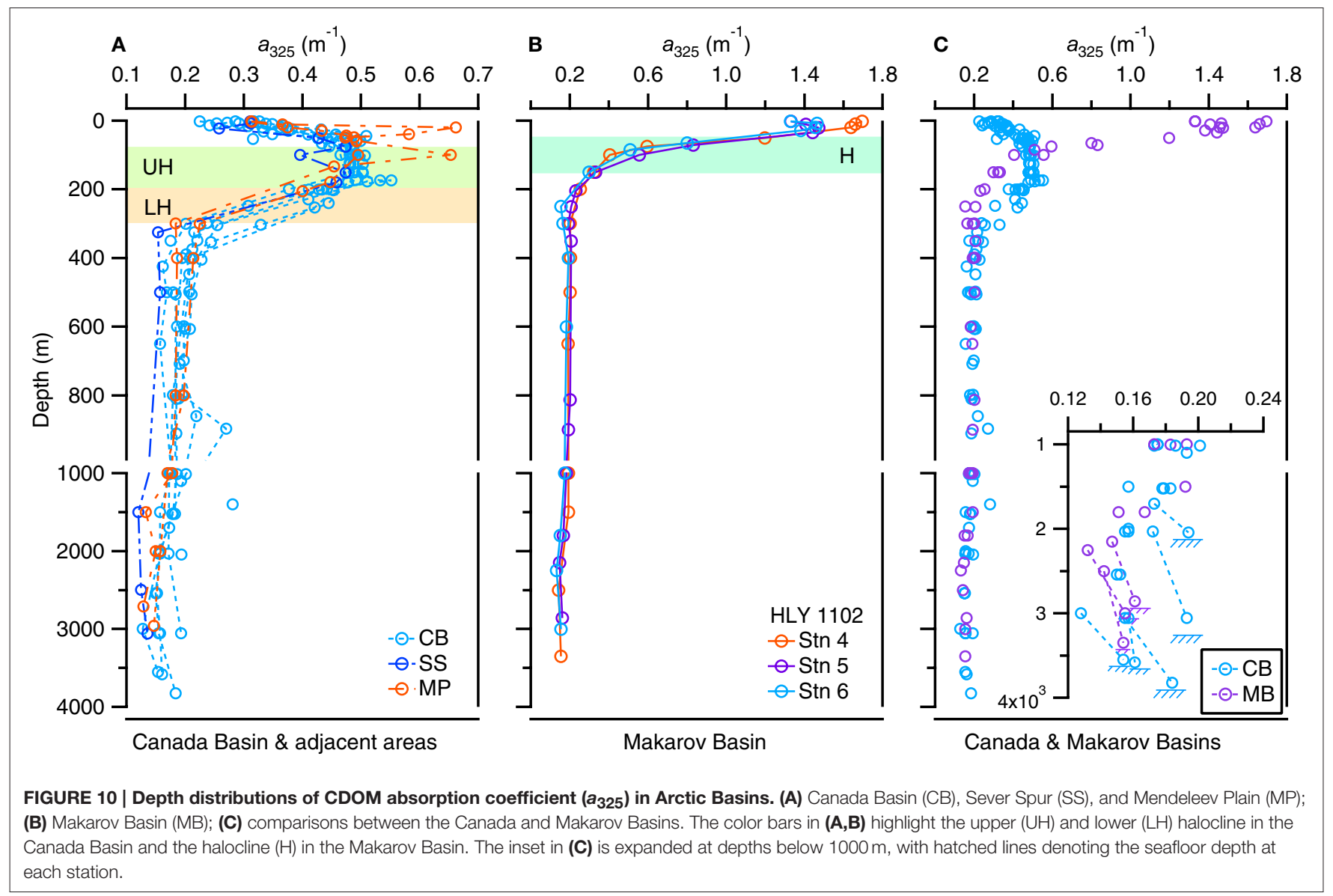

waters in the Canada Basin. Previous investigations (2002-2004) do not report such high concentrations of DOC in similar regions (mostly 65-80 $\mu \mathrm{mol} \mathrm{L}^{-1}$; Mathis et al., 2005; Shen et al., 2012). This large inter-annual variability in terrigenous DOM concentrations is consistent with a recent change in the routing of Mackenzie River outflow, which has shifted from a predominantly eastward path to a northwestward path since 2006 in response to climatic variability (Fichot et al., 2013). The routing switch enhanced the input of terrigenous DOM to the Canada Basin.

Contrasting DOM characteristics were present in surface waters of the Canada and Makarov Basins, reflecting distinct sources and processing of DOM. Surface waters of the Canada Basin contained relatively high $f_{\mathrm{MW}}(0.18 \pm 0.01)$ but had lower DOC concentrations (Table 2) and CDOM absorption (Stedmon et al., 2011; Guéguen et al., 2015) compared to other Arctic Basins. This feature appears to result from a substantial contribution of precipitation in the inflowing waters from the Pacific Ocean and a lesser contribution of freshwater from continental runoff (Woodgate and Aagaard, 2005; YamamotoKawai et al., 2008). Although high $f_{\text {SIM }}$ was observed in surface waters, as discussed below, this had a negligible influence on the surface DOC concentrations. Relatively low concentrations of lignin phenols $\left(2-4 \mathrm{nmol} \mathrm{L}^{-1}\right)$ were observed over large areas of the Canada Basin, due in part to minor contributions of continental runoff. Surface waters in the Beaufort Gyre have a decadal residence time that allows substantial removal of DOM (Rutgers van der Loeff et al., 1995; Hansell et al., 2004; Cooper et al., 2005). The $S_{275-295}$ values were high $\left(>30 \mu \mathrm{m}^{-1}\right)$ and elevated in ice-free waters, indicating photobleaching and potential removal of DOC due to coupled photochemical and biological degradation (Fichot and Benner, 2014).

By contrast, surface waters in the Makarov Basin had a lower $f_{\mathrm{MW}}(0.15 \pm 0.02)$ but were characterized by much higher DOC concentrations and CDOM absorption and lower $S_{275-295}$ values compared to Canada Basin surface waters (Table 2). The high concentrations of lignin phenols $\left(15 \pm 3 \mathrm{nmol} \mathrm{L}^{-1}\right)$ in surface waters were indicative of a strong Siberian river influence associated with the Transpolar Drift (Opsahl et al., 1999; Benner et al., 2005). The Siberian rivers (e.g., Lena River) have higher concentrations of DOC than the Mackenzie River (Anderson and Amon, 2015; and reference therein). In addition, unlike the long-term processing in the Canada Basin, DOM entering the Makarov Basin is rapidly transported $(<1-3 \mathrm{yr})$ by the Transpolar Drift (Rutgers van der Loeff et al., 1995). Concentrations of DOC $\left(114 \pm 5 \mu \mathrm{mol} \mathrm{L}^{-1}\right)$ and lignin phenols $\left(17 \pm 1 \mathrm{nmol} \mathrm{L}^{-1}\right)$ determined here for the Transpolar Drift $\left(>83^{\circ} \mathrm{N}\right)$ were comparable to values measured at similar salinities $(\sim 30)$ in waters off the Siberian shelves (Guay et al., 1999; Kattner et al., 1999; Kaiser et al., in review), suggesting minor losses of DOM occurred during transport to the central Arctic. 


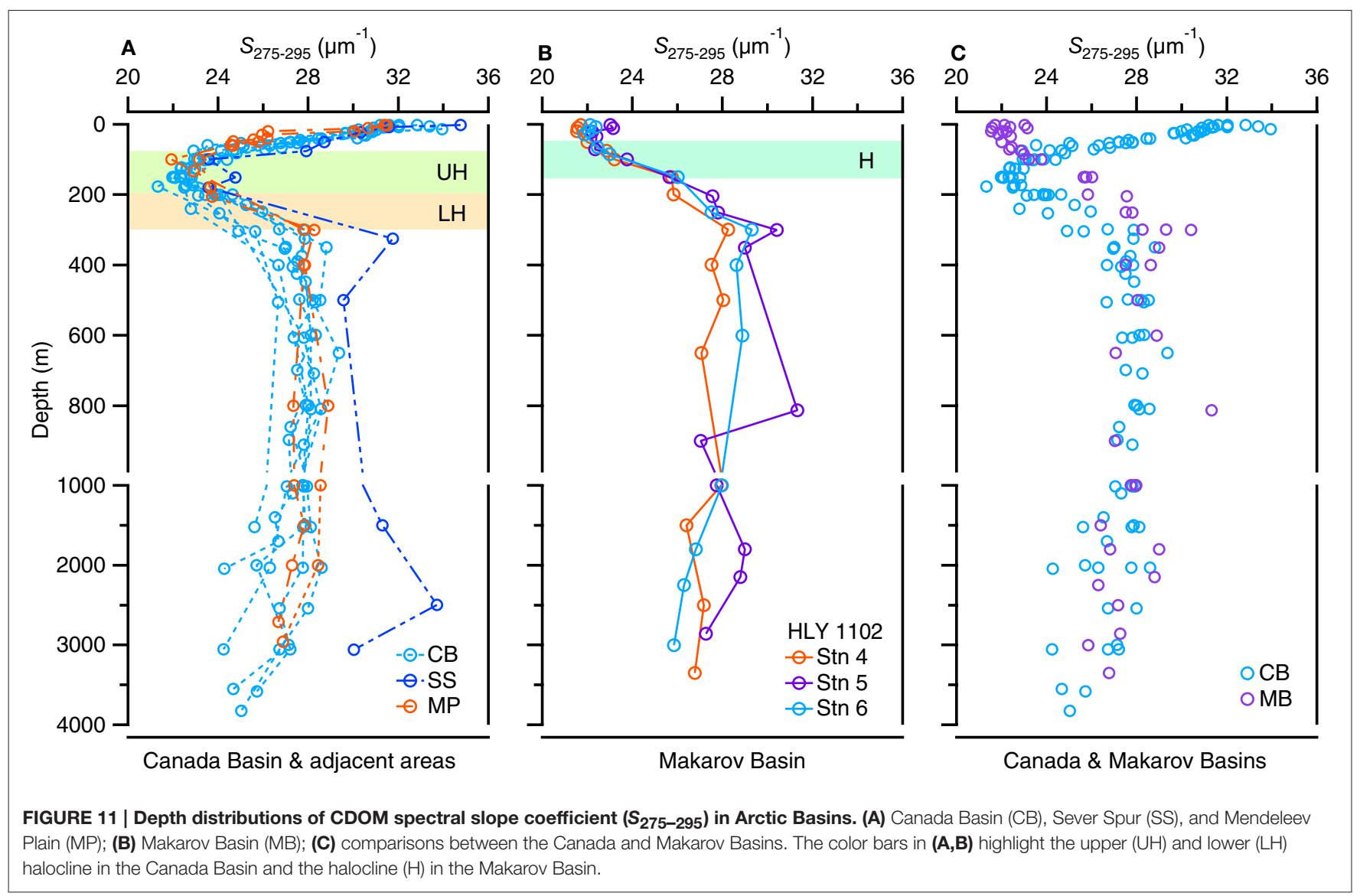

The axis of the Transpolar Drift is variable and shifts between the Mendeleev and Lomonosov Ridges, depending on the phase of the Arctic Oscillation (AO) (Guay et al., 2001; Mysak, 2001; Steele et al., 2004). A negative AO phase dominated the summers of 2010-2011 and resulted in a deflection of the Transpolar Drift toward the Lomonosov Ridge and a strengthened Beaufort Gyre. Under these conditions the Eurasian runoff and terrigenous DOM entrained in the Transpolar Drift would be confined mainly to regions between the Mendeleev and Lomonosov Ridges (Mysak, 2001). Such routing of the Transpolar Drift was substantiated by observations of relatively low concentrations of DOC, lignin phenols and $a_{325}$ values, and high values of $S_{275-295}$ over the Mendeleev Plain. This route would bypass the Canada Basin and thereby favors export of DOM to the North Atlantic Ocean. These results revealed contrasting distributions and fates of DOM between the Canada and Makarov Basins and further highlighted strong hydrographic controls on the DOC cycle in the Arctic Ocean.

\section{Influence of Sea-Ice Melt on DOM in Surface Waters}

The effect of sea-ice melt on DOC concentrations in underlying waters depends on the biota and organic compounds within the ice. Sea-ice formation excludes DOM as well as salts (Giannelli et al., 2001; Amon, 2004), whereas ice algae, other microorganisms and entrained sediments with associated organic matter can contribute high concentrations of organic carbon to the ice (Smith et al., 1997; Eicken, 2004; Gradinger, 2009). The spatial and temporal variability of biota and organic matter in Arctic sea ice are high (Thomas et al., 1995; Smith et al., 1997; Song et al., 2011), thereby complicating the net impact of sea-ice melt on DOC concentrations. Previous studies report similarly variable observations (Anderson, 2002; Eicken, 2004; Mathis et al., 2005, 2007; Anderson and Amon, 2015; Logvinova et al., 2016).

Results of this study demonstrated that the influence of seaice melt on concentrations and compositions of DOM in polar surface waters was region-dependent. Contrasting effects of seaice melt were observed along the margin between the Beaufort Sea and the Bering-Chukchi Seas, and it appeared to be related to the influence of continental runoff. Sea ice formed on the riverinfluenced Beaufort Shelf includes suspended riverine materials (i.e., "dirty" ice; Eicken et al., 2005). Melting of this "dirty" ice can potentially release high concentrations of terrigenous organic matter and increase DOM concentrations in the surface layer. The significance of these processes was apparent in the Beaufort Sea from the observation of elevated lignin concentrations in waters containing higher $f_{\mathrm{MW}}$.

In the Bering-Chukchi Seas negative relationships between DOC, lignin phenols, CDOM and $f_{\mathrm{MW}}$ indicated a low abundance of organic matter in the ice. Terrigenous inputs inferred from $f_{\mathrm{MW}}(0.07 \pm 0.04)$ and lignin phenol 


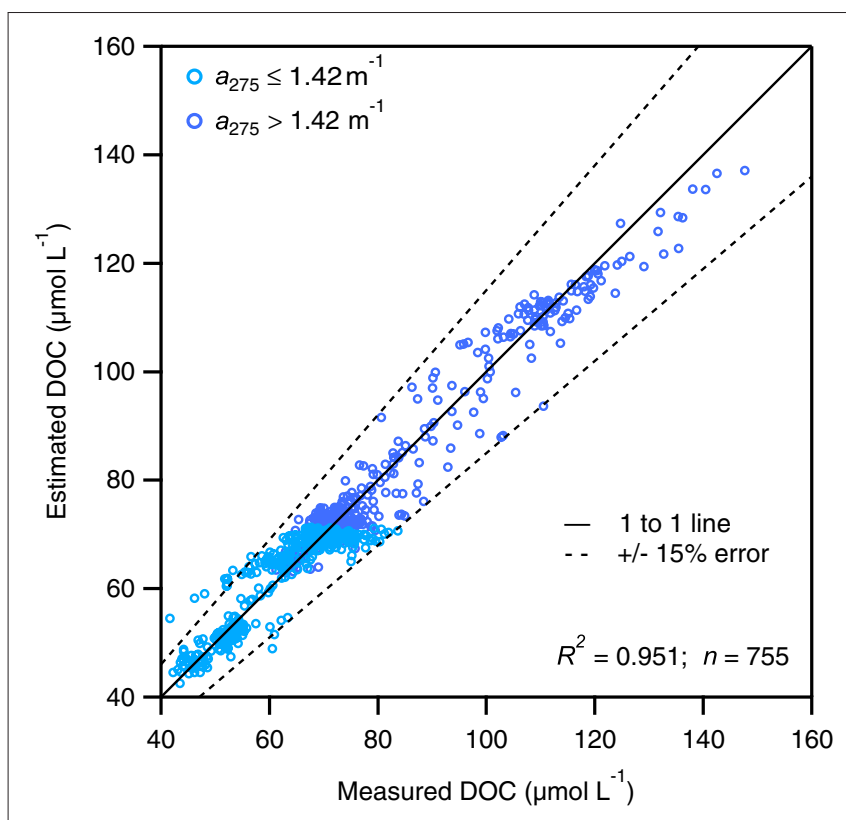

FIGURE 12 | Plot of DOC estimated from CDOM analysis vs. measured DOC. Estimated DOC is calculated from CDOM absorption coefficients at 275 $\mathrm{nm}\left(\mathrm{a}_{275}\right)$ and $295 \mathrm{~nm}\left(\mathrm{a}_{295}\right)$ using two multi-linear regression models separated by $a_{275}=1.42 \mathrm{~m}^{-1}$ cutoff. The regression coefficients used in the two models are provided in Equations (5) and (6).

concentrations $\left(4 \pm 3 \mathrm{nmol} \mathrm{L}^{-1}\right.$ ) were relatively low in the Bering-Chukchi Seas. Ice algae production in this region is high (Gosselin et al., 1997; Gradinger, 2009), but algal contributions of DOM are often confined to the bottom of the ice (Thomas et al., 1995; Smith et al., 1997; Song et al., 2011). Previous analyses of ice cores in the Chukchi Sea indicate variable but generally lower DOC concentrations and CDOM absorption than found in adjacent surface waters (Krembs et al., 2002; Mathis et al., 2007; Logvinova et al., 2016). Our results add to these observations indicating a dilution effect of sea-ice melt on DOM in the Bering-Chukchi Seas during August-September.

The influence of sea-ice melt on DOM in surface waters of the deep basins is minor. Extensive sea-ice melt was observed in surface waters of the Canada Basin and southern Mendeleev Plain. However, the melting of sea ice did not result in significant changes in surface concentrations of DOC, lignin phenols, and $a_{325}$ values in the region. The lack of significant response to seaice melt indicates concentrations of DOM in the melted ice were comparable to those in the underlying waters. Considering the large difference in terrigenous influence, sea ice in the Canada Basin and Mendeleev Plain likely contained much less DOM than sea ice found in the central Arctic and Fram Strait (e.g., <100-300 $\mu \mathrm{mol} \mathrm{L}^{-1}$; Melnikov, 1997; Opsahl et al., 1999).

\section{Abundance and Distribution of DOM in Halocline and Atlantic Waters}

Halocline waters of the Canada and Makarov Basins displayed distinct DOM distributions related to their sources and formation. A prominent feature in the Canada Basin was the maximal $a_{325}\left(0.48 \pm 0.03 \mathrm{~m}^{-1}\right)$ and minimal $S_{275-295}(22.9$ $\left.\pm 0.7 \mu \mathrm{m}^{-1}\right)$ in the upper halocline, which indicated higher molecular weight chromophores and minimal photobleaching. Upper halocline waters are derived from brine rejection during sea-ice formation over the Chukchi and East Siberian shelves, where nutrients and organic matter released from sediments are added to the dense brines and advected into the Canada Basin (Jones and Anderson, 1986; Cooper et al., 1997, 2005). These processes are an important source of CDOM in the upper halocline (Cooper et al., 2005; Guéguen et al., 2007; Stedmon et al., 2011) and they were apparent from our observations of negative $f_{\text {SIM }}$ and elevated inorganic nutrients. Concentrations of dissolved lignin phenols in the upper halocline $(3 \pm 0.2$ nmol L $\left.{ }^{-1}\right)$ were similar to values $\left(3 \pm 0.4 \mathrm{nmol} \mathrm{L}^{-1}\right)$ in surface waters, indicating a terrigenous signature associated with brine waters. These results are consistent with previous observations of relatively high concentrations of lignin phenols and $\Delta^{14} \mathrm{C}$ in DOC of upper halocline waters (Benner et al., 2004), demonstrating a contemporary riverine DOM source. Previous observations of elevated CDOM in the upper halocline were mainly from the southern Canada Basin (Cooper et al., 2005; Guéguen et al., 2007; Nakayama et al., 2011). Our results indicate these CDOM characteristics can be traced throughout the central and northern Canada Basin.

In contrast with the Canada Basin, DOC concentrations and CDOM absorption in the Makarov Basin were highest in surface waters and decreased rapidly with depth in the upper $200 \mathrm{~m}$ of the water column. The average values of DOC concentrations $(70 \pm 14 \mu \mathrm{mol} \mathrm{L}-1), a_{325}$ values $\left(0.58 \pm 0.29 \mathrm{~m}^{-1}\right), S_{275-295}$ values $\left(23.7 \pm 1.5 \mu \mathrm{m}^{-1}\right)$, and lignin phenol concentrations (4 $\left.\pm 4 \mathrm{nmol} \mathrm{L}{ }^{-1}\right)$ in the halocline were comparable to those in upper halocline of the Canada Basin. Atlantic water that flows through Fram Strait and is modified over the Eurasian shelves supplies the halocline in the Makarov Basin (Rudels et al., 1996, 2004; Bauch et al., 2016). The Atlantic inflow waters in the Fram Strait have relatively low concentrations of DOC $(\sim 61$ $\left.\mu \mathrm{mol} \mathrm{L}{ }^{-1}\right)$ and CDOM $\left(a_{350}<0.2 \mathrm{~m}^{-1}\right)$ (Opsahl et al., 1999; Amon et al., 2003; Granskog et al., 2012). Sea-ice formation and brine rejection over the Siberian shelves can transport elevated concentrations of DOC and CDOM from Siberian rivers to the halocline. The relatively high concentrations of lignin phenols indicate an important riverine contribution to the DOC and CDOM in halocline waters. Distributions of DOC, $a_{325}$, and lignin phenols along the salinity gradient in the halocline were largely conservative $\left(R^{2}=0.78-0.92\right)$, indicating minimal loss of DOM components during transport within halocline waters of the Makarov Basin.

The DOC concentrations and CDOM absorption in Atlantic waters below the halocline were similar between the Canada Basin and Makarov Basin. Comparisons with previous DOC measurements revealed two particular features: little interannual variability within the Canada and Makarov Basins and a concentration gradient between the Canadian and Eurasian Basins. Average concentrations of DOC in Atlantic waters decreased from $60 \pm 5 \mu \mathrm{mol} \mathrm{L}{ }^{-1}$ in the Nansen Basin to $56 \pm$ $2 \mu \mathrm{mol} \mathrm{L}-1$ in the Amundsen Basin, and to $52-55 \mu \mathrm{mol} \mathrm{L}-1$ in the Canada Basin (Table 2). These DOC values were also lower than those in the inflowing Atlantic water ( $<600 \mathrm{~m} ; 61 \mu \mathrm{mol} \mathrm{L}^{-1}$; 
TABLE 2 | Concentrations of dissolved organic carbon (DOC) in Arctic Basins.

\begin{tabular}{|c|c|c|c|c|c|}
\hline Region & Latitude, longitude & Depth (m) & $\mathrm{DOC}\left(\mu \mathrm{mol} \mathrm{L} \mathrm{L}^{-1}\right)$ & $n$ & References \\
\hline \multicolumn{6}{|c|}{ POLAR MIXED LAYER } \\
\hline Canada Basin & $72-83^{\circ} \mathrm{N}, 127-162^{\circ} \mathrm{W}$ & $0-80$ & $69 \pm 6(52-88)$ & 144 & This study \\
\hline Canada Basin & $70-75^{\circ} \mathrm{N}, 127-138^{\circ} \mathrm{W}$ & $\sim 10$ & $69 \pm 11(61-88)$ & 8 & Letscher et al., 2011 \\
\hline Canada Basin & $71-74^{\circ} \mathrm{N}, 134-160^{\circ} \mathrm{W}$ & $0-30$ & $74 \pm 4(66-81)$ & 19 & Davis and Benner, 2005; Shen et al., 2012 \\
\hline Canada Basin & $71-74^{\circ} \mathrm{N}, 145-160^{\circ} \mathrm{W}$ & - & $71 \pm 4(50-90)$ & 54 & Mathis et al., 2005 \\
\hline Makarov Basin & $85-88^{\circ} \mathrm{N}, 143^{\circ} \mathrm{E}-153^{\circ} \mathrm{W}$ & $0-35$ & $108 \pm 9(81-129)$ & 59 & This study \\
\hline Makarov Basin & $80-81^{\circ} \mathrm{N}, 157^{\circ} \mathrm{E}-177^{\circ} \mathrm{W}$ & $\sim 10$ & $92 \pm 26(70-124)$ & 5 & Letscher et al., 2011 \\
\hline Makarov Basin & $81-87^{\circ} \mathrm{N}, 167-179^{\circ} \mathrm{E}$ & $0-25$ & $107 \pm 19$ & 15 & Wheeler et al., 1997 \\
\hline Amundsen Basin & $80-81^{\circ} \mathrm{N}, 128-148^{\circ} \mathrm{E}$ & $\sim 10$ & $93 \pm 4(90-102)$ & 6 & Letscher et al., 2011 \\
\hline Amundsen Basin & $88-90^{\circ} \mathrm{N}, 32-148^{\circ} \mathrm{E}$ & $0-25$ & $99 \pm 8$ & 9 & Wheeler et al., 1997 \\
\hline Nansen Basin & $78-81^{\circ} \mathrm{N}, 116-122^{\circ} \mathrm{E}$ & $\sim 10$ & $83 \pm 10(71-99)$ & 6 & Letscher et al., 2011 \\
\hline Nansen Basin & $84-86^{\circ} \mathrm{N}, 34-38^{\circ} \mathrm{E}$ & $0-25$ & $65 \pm 11$ & 8 & Wheeler et al., 1997 \\
\hline \multicolumn{6}{|c|}{ HALOCLINE WATER } \\
\hline Canada Basin & $72-84^{\circ} \mathrm{N}, 128-158^{\circ} \mathrm{W}$ & 50-300 & $64 \pm 3(57-75)$ & 37 & This study \\
\hline Canada Basin & $70-74^{\circ} \mathrm{N}, 134-160^{\circ} \mathrm{W}$ & $50-250$ & $66 \pm 6(53-79)$ & 77 & Davis and Benner, 2005; Shen et al., 2012 \\
\hline Canada Basin & $71-74^{\circ} \mathrm{N}, 145-160^{\circ} \mathrm{W}$ & - & $63 \pm 3(59-68)$ & 59 & Mathis et al., 2005 \\
\hline Makarov Basin & $86-88^{\circ} \mathrm{N}, 166-176^{\circ} \mathrm{W}$ & $50-150$ & $70 \pm 14(56-101)$ & 10 & This study \\
\hline Makarov Basin & $81-87^{\circ} \mathrm{N}, 167-179^{\circ} \mathrm{E}$ & $30-150$ & $82 \pm 22$ & 13 & Wheeler et al., 1997 \\
\hline Makarov Basin & $78-81^{\circ} \mathrm{N}, 160-173^{\circ} \mathrm{E}$ & 58 & $97 \pm 11(64-124)$ & 27 & Guay et al., 1999 \\
\hline Amundsen Basin & $88-90^{\circ} \mathrm{N}, 32-148^{\circ} \mathrm{E}$ & $30-150$ & $74 \pm 7$ & 7 & Wheeler et al., 1997 \\
\hline Amundsen Basin & $79-80^{\circ} \mathrm{N}, 130-138^{\circ} \mathrm{E}$ & 58 & $74 \pm 9(64-91)$ & 15 & Guay et al., 1999 \\
\hline Nansen Basin & $84-86^{\circ} \mathrm{N}, 34-38^{\circ} \mathrm{E}$ & $30-150$ & $66 \pm 10$ & 10 & Wheeler et al., 1997 \\
\hline \multicolumn{6}{|c|}{ ATLANTIC WATER } \\
\hline Canada Basin & $72-84^{\circ} \mathrm{N}, 128-158^{\circ} \mathrm{W}$ & $300-1000$ & $53 \pm 3(50-63)$ & 33 & This study \\
\hline Canada Basin & $72-74^{\circ} \mathrm{N}, 152-160^{\circ} \mathrm{W}$ & $300-800$ & $55 \pm 4$ (50-69) & 22 & Davis and Benner, 2005 \\
\hline Canada Basin & $72-74^{\circ} \mathrm{N}, 152-158^{\circ} \mathrm{W}$ & $300-800$ & $52 \pm 6(45-62)$ & 6 & Benner, unpublished \\
\hline Canada Basin & $71-74^{\circ} \mathrm{N}, 150-160^{\circ} \mathrm{W}$ & - & $53 \pm 2(48-57)$ & 39 & Mathis et al., 2005 \\
\hline Makarov Basin & $86-88^{\circ} \mathrm{N}, 166-176^{\circ} \mathrm{W}$ & $200-800$ & $54 \pm 4(44-62)$ & 14 & This study \\
\hline Makarov Basin & $81-87^{\circ} \mathrm{N}, 167-179^{\circ} \mathrm{E}$ & 200-300 & $55 \pm 5$ & 5 & Wheeler et al., 1997 \\
\hline Amundsen Basin & $88-90^{\circ} \mathrm{N}, 32-148^{\circ} \mathrm{E}$ & 200-300 & $56 \pm 2$ & 2 & Wheeler et al., 1997 \\
\hline Nansen Basin & $84-86^{\circ} \mathrm{N}, 34-38^{\circ} \mathrm{E}$ & $200-300$ & $60 \pm 5$ & 2 & Wheeler et al., 1997 \\
\hline Nordic Seas & - & $50-600$ & $58 \pm 5$ & 54 & Amon et al., 2003 \\
\hline \multicolumn{6}{|c|}{ ARCTIC DEEP AND BOTTOM WATERS } \\
\hline Canada Basin & $72-84^{\circ} \mathrm{N}, 128-158^{\circ} \mathrm{W}$ & 1000-2500 & $49 \pm 3(44-56)$ & 18 & This study \\
\hline Canada Basin & $72-74^{\circ} \mathrm{N}, 152-160^{\circ} \mathrm{W}$ & $1000-2500$ & $50 \pm 3(44-55)$ & 21 & Davis and Benner, 2005 \\
\hline Canada Basin & $72-74^{\circ} \mathrm{N}, 152-160^{\circ} \mathrm{W}$ & $1000-2500$ & $49 \pm 2(46-52)$ & 8 & Benner, unpublished \\
\hline Canada Basin & $72-84^{\circ} \mathrm{N}, 128-158^{\circ} \mathrm{W}$ & $2500-4000$ & $46 \pm 1(44-47)$ & 7 & This study \\
\hline Canada Basin & $72-74^{\circ} \mathrm{N}, 152-160^{\circ} \mathrm{W}$ & $2500-4000$ & $47 \pm 3(43-51)$ & 8 & Davis and Benner, 2005 \\
\hline Canada Basin & $72-74^{\circ} \mathrm{N}, 152-160^{\circ} \mathrm{W}$ & $2500-4000$ & $47 \pm 5(41-51)$ & 3 & Benner, unpublished \\
\hline Canada Basin & $71-74^{\circ} \mathrm{N}, 150-160^{\circ} \mathrm{W}$ & $>1000$ & $47 \pm 1(45-50)$ & 19 & Mathis et al., 2005 \\
\hline Makarov Basin & $85^{\circ} \mathrm{N}, 140-170^{\circ} \mathrm{E}$ & $>1000$ & $56(29-100)$ & 32 & Bussmann and Kattner, 2000 \\
\hline Makarov Basin & $86-88^{\circ} \mathrm{N}, 166-176^{\circ} \mathrm{W}$ & 1000-2500 & $49 \pm 4(43-54)$ & 10 & This study \\
\hline Makarov Basin & $86-88^{\circ} \mathrm{N}, 166-176^{\circ} \mathrm{W}$ & $2500-3500$ & $46 \pm 2(44-49)$ & 3 & This study \\
\hline Amundsen Basin & - & $>1000$ & $54(34-79)$ & 67 & Bussmann and Kattner, 2000 \\
\hline Nansen Basin & - & $>1000$ & $50(36-112)$ & 53 & Bussmann and Kattner, 2000 \\
\hline Eurasian Basin & - & 1800-2500 & $50 \pm 2$ & 20 & Amon et al., 2003 \\
\hline \multicolumn{6}{|l|}{ NORDIC SEAS } \\
\hline Greenland Sea & - & 2500-4000 & $50 \pm 2$ & 22 & Amon et al., 2003 \\
\hline Greenland Sea & $75^{\circ} \mathrm{N}, 0^{\circ} \mathrm{W}$ & $1000-4000$ & $48 \pm 0.3$ & 10 & Hansell and Carlson, 1998 \\
\hline Norwegian Sea & $70-72^{\circ} \mathrm{N}, 0-2^{\circ} \mathrm{W}$ & 2000-3500 & $48 \pm 2$ & 4 & Amon et al., 2003 \\
\hline
\end{tabular}

Data are reported as average \pm standard deviation (range). 
Opsahl et al., 1999; Amon et al., 2003), indicating DOC removal from Atlantic waters during transport in the Arctic Ocean.

\section{DOC and CDOM in Deep Arctic Waters}

Concentrations of DOC in the deep Arctic Ocean exhibited a strong vertical gradient at depths of $1000-2500 \mathrm{~m}$ and a relatively homogenous distribution at depths $>2500 \mathrm{~m}$. The variability in deep DOC concentrations observed in this study was considerably lower than that reported by Bussmann and Kattner (2000) (Table 2). On average, concentrations of DOC in deep waters (1000-2500 m) of the Canada Basin (49 $\pm 3 \mu \mathrm{mol}$ $\left.\mathrm{L}^{-1}\right)$ and Makarov Basin $\left(49 \pm 4 \mu \mathrm{mol} \mathrm{L}^{-1}\right)$ were similar to but slightly lower than those in deep waters of the Amundsen Basin $\left(54 \mu \mathrm{mol} \mathrm{L}^{-1}\right)$, Nansen Basin $\left(50 \mu \mathrm{mol} \mathrm{L}^{-1}\right)$, outflowing deep waters from the Eurasian Basin (1800-2500 m; $50 \pm 2 \mu \mathrm{mol} \mathrm{L}^{-1}$ ), and Nordic Seas deep waters (1000-4000 m; 48-50 $\mu \mathrm{mol} \mathrm{L}^{-1}$; Table 2). Concentrations of DOC in bottom waters of the Canada and Makarov Basins (>2500 m; $46 \pm 2 \mu \mathrm{mol} \mathrm{L}^{-1}$ ) were lower than those in any Arctic water masses mentioned above, but they were higher than concentrations in deep waters of other major ocean basins (35-45 $\mu \mathrm{mol} \mathrm{L}^{-1}$; Druffel et al., 1992; Hansell and Carlson, 1998).

There are few CDOM measurements in Arctic deep waters. The $a_{325}$ measured herein at depths $>1000 \mathrm{~m}$ in the Canada Basin $\left(0.17 \pm 0.02 \mathrm{~m}^{-1}\right)$ and Makarov Basin $\left(0.16 \pm 0.02 \mathrm{~m}^{-1}\right)$ were within the range in deep waters $(>2000 \mathrm{~m}$ ) of the South Atlantic and North Indian Oceans, but were slightly elevated relative to those in deep waters ( $>2000 \mathrm{~m} ; 0.10-0.15 \mathrm{~m}^{-1}$ ) of the Pacific, North Atlantic, and South Indian Oceans (Nelson et al., 2010).

An outstanding feature of the deep-Arctic data was that concentrations of DOC decreased (by $6-8 \mu \mathrm{mol} \mathrm{L}^{-1}$ ) with increasing water mass ages from depths of $1000 \mathrm{~m}$ to $2500 \mathrm{~m}$ in the Canada and Makarov Basins. Such a loss of DOC resembled the gradient $\left(6 \pm 1 \mu \mathrm{mol} \mathrm{L}^{-1}\right)$ observed in North Atlantic Deep Water from $65^{\circ} \mathrm{N}$ to $19^{\circ} \mathrm{N}$ (Carlson et al., 2010). The decline in deep Arctic DOC concentrations was significantly related to an increase in salinity, apparent oxygen utilization and nutrient concentrations, indicating that physical mixing and microbial degradation are responsible for the decline in DOC concentrations. The radiocarbon content of DOC in Canada Basin deep water decreases from $-380 \%$ at $1000 \mathrm{~m}$, a value close to that in North Atlantic deep water, to $-466 \%$ at $2500 \mathrm{~m}$ (Griffith et al., 2012). The difference in $\Delta^{14} \mathrm{C}(-86 \%)$ indicates the DOC ages vary by over $700 \mathrm{yr}$ between 1000 and $2500 \mathrm{~m}$, whereas the CFC-based ventilation age of water increases by $\sim 200$ yr. These differences between DOC and ventilation ages indicate the DOC that is removed is ${ }^{14} \mathrm{C}$-enriched relative to the bulk DOC.

Assuming the decrease in deep-water DOC concentrations was all due to microbial degradation, estimates of maximal degradation rates can be derived from the regression slope between DOC concentrations and ventilation ages at depths of $1000-2500 \mathrm{~m}\left(R^{2}=0.51-0.83, p<0.001\right)$. The estimated rates ranged from $0.036 \mu \mathrm{mol} \mathrm{C} \mathrm{L} \mathrm{yr}^{-1}$ in the Canada Basin to 0.039 $\mu$ mol C L ${ }^{-1} \mathrm{yr}^{-1}$ in the Makarov Basin, and they represent the upper limits for DOC biodegradation in these deep waters. These values were 2-3 orders of magnitude lower than those $(0.2-5$ $\mu$ mol C L ${ }^{-1} \mathrm{yr}^{-1}$ ) estimated in the mesopelagic zone of the North Pacific and North Atlantic (Carlson et al., 2010; Kaiser and Benner, 2012), and they were also lower than those (0.04-0.20 $\mu \mathrm{mol} \mathrm{C} \mathrm{L} \mathrm{L}^{-1} \mathrm{yr}^{-1}$ ) in deep waters (>1000 $\mathrm{m}$ ) of the Greenland Gyre, North Atlantic Ocean, Mediterranean Sea, and East Japan Sea (Amon et al., 2003; Carlson et al., 2010; Kim et al., 2015). These comparisons indicate slow microbial degradation of DOC in deep waters of the Arctic Ocean. In addition to the relatively low abundance of bioavailable DOM in deep waters (Amon and Benner, 2003; Davis and Benner, 2005), low water temperatures $\left(<0^{\circ} \mathrm{C}\right)$ could also influence rates of microbial degradation of DOM in the deep ocean (e.g., Kim et al., 2015).

An unexpected elevation of $a_{325}$ (by 10-20\%) with minor changes in DOC concentrations was observed near the seafloor (mostly $<50 \mathrm{~m}$ above the bottom) in the Canada and Makarov Basins. Our observations differ from those of Bussmann and Kattner (2000) who reported losses of DOC near the seafloor around the Lomonosov Ridge. The elevated $a_{325}$ we observed near the seafloor was associated with lower $S_{275-295}$ values and higher nutrient concentrations, suggesting that the elevated CDOM was largely derived from benthic remineralization of organic matter in sediments. This observation is in agreement with growing data on benthic abundance, diversity, and carbon demand indicating active biological processing in sediments of deep Arctic Ocean basins (Clough et al., 1997; Klages et al., 2004; Bluhm et al., 2011). Overall, these data indicate DOC and CDOM in Arctic Ocean deep and bottom waters are more dynamic than previously recognized.

\section{AUTHOR CONTRIBUTIONS}

LR and RB designed the study. LR and JW collected the DOM, nutrient and isotope samples onboard the Healy. JW analyzed the isotope samples. YS analyzed the DOC and CDOM. YS and RB wrote the manuscript with comments from LR and JW.

\section{ACKNOWLEDGMENTS}

We thank the captains and crews of the US Coast Guard Cutter Healy during cruises HLY1002, 1102, and 1202. We also thank Brian Edwards, Chief Scientist on HLY1002, and Larry Mayer and Andy Armstrong, Co-Chief Scientists on HLY1102 and 1202, for their support of this non-interference science during the U.S. Extended Continental Shelf Task Force cruises. This work was funded by the USGS Coastal and Marine Geology Program and Office of Regional Executive-Alaska, and by NSF Division of Polar Programs (PLR-1220032) and NOAA Office of Climate Observation. RB and YS acknowledge support from the NSF Division of Polar Programs (PLR-1504137). Any use of trade, firm, or product names is for descriptive purposes only and does not imply endorsement by the U.S. Government.

\section{SUPPLEMENTARY MATERIAL}

The Supplementary Material for this article can be found online at: http://journal.frontiersin.org/article/10.3389/fmars. 2016.00198 


\section{REFERENCES}

Alkire, M. B., Morison, J., and Andersen, R. (2015). Variability in the meteoric water, sea-ice melt, and Pacific water contributions to the central Arctic Ocean, 2000-2014. J. Geophys. Res. 120, 1573-1598. doi: 10.1002/2014JC010023

Amon, R. (2004). "The role of dissolved organic matter for the organic carbon cycle in the Arctic Ocean," in The Organic Carbon Cycle in the Arctic Ocean, eds R. Stein and R. MacDonald (Berlin: Springer-Verlag), 83-99.

Amon, R. M. W., and Benner, R. (2003). Combined neutral sugars as indicators of the diagenetic state of dissolved organic matter in the Arctic Ocean. Deep-Sea Res. Part I 50, 151-169. doi: 10.1016/S0967-0637(02)00130-9

Amon, R. M. W., Budeus, G., and Meon, B. (2003). Dissolved organic carbon distribution and origin in the Nordic Seas: exchanges with the Arctic Ocean and the North Atlantic. J. Geophys. Res.-Oceans 108, C7. doi: 10.1029/2002JC001594

Anderson, L. (2002). "DOC in the Arctic Ocean," in Biogeochemistry of Marine Dissolved Organic Matter, eds D. A. Hansell and C. A. Carlson (Boston, MA: Academic Press), 665-683.

Anderson, L. G., and Amon, R. M. W. (2015). "DOM in the Arctic Ocean," in Biogeochemistry of Marine Dissolved Organic Matter, 2nd Edn., eds D. A. Hansell and C. A. Carlson (Boston, MA: Academic Press), 609-633.

Anderson, L. G., Olsson, K., and Skoog, A. (1994). Distribution of dissolved inorganic and organic carbon in the Eurasian Basin of the Arctic Ocean. J. Geophys. Res. 99, 3273-3283. doi: 10.1029/93JC02977

Bauch, D., Cherniavskaia, E., and Timokhov, L. (2016). Shelf basin exchange along the Siberian continental margin: modification of Atlantic Water and Lower Halocline Water. Deep-Sea Res. Part I 115, 188-198. doi: 10.1016/j.dsr.2016.06.008

Bauch, D., Schlosser, P., and Fairbanks, R. G. (1995). Freshwater balance and the sources of deep and bottom waters in the Arctic Ocean inferred from the distribution of $\mathrm{H}_{2}{ }^{18} \mathrm{O}$. Prog. Oceanogr. 35, 53-80. doi: 10.1016/00796611(95)00005-2

Benner, R., Benitez-Nelson, B., Kaiser, K., and Amon, R. M. W. (2004). Export of young terrigenous dissolved organic carbon from rivers to the Arctic Ocean. Geophys. Res. Lett. 31, L05305. doi: 10.1029/2003GL019251

Benner, R., Louchouarn, P., and Amon, R. M. W. (2005). Terrigenous dissolved organic matter in the Arctic Ocean and its transport to surface and deep waters of the North Atlantic. Global Biogeochem. Cycles 19, GB2025. doi: 10.1029/2004GB002398

Benner, R., and Strom, M. (1993). A critical evaluation of the analytical blank associated with DOC measurements by high-temperature catalytic oxidation. Mar. Chem. 41, 153-160. doi: 10.1016/0304-4203(93)90113-3

Bluhm, A. B., Ambrose W. G. Jr., Bergmann, M., Clough, L. M., Gebruk, A. V., Hasemann, C., et al. (2011). Diversity of the arctic deep-sea benthos. Mar. Biodivers. 41, 87-107. doi: 10.1007/s12526-010-0078-4

Bluhm, A. B., Kosobokova, K., and Carmack, E. (2015). A tale of two basins: an integrated physical and biological perspective of the deep Arctic Ocean. Prog. Oceanogr. 139, 89-121. doi: 10.1016/j.pocean.2015.07.011

Bussmann, I., and Kattner, G. (2000). Distribution of dissolved organic carbon in the central Arctic Ocean: the influence of physical and biological properties. J. Mar. Syst. 27, 209-219. doi: 10.1016/S0924-7963(00)00068-3

Carlson, C. A., Hansell, D. A., Nelson, N. B., Siegel, D. A., Smethie, W. M., Khatiwala, S., et al. (2010). Dissolved organic carbon export and subsequent remineralization in the mesopelagic and bathypelagic realms of the North Atlantic basin. Deep-Sea Res. Part II Top. Stud. Oceanogr. 57, 1433-1445. doi: 10.1016/j.dsr2.2010.02.013

Carmack, E., Winsor, P., and Williams, W. (2015). The contiguous panarctic Riverine Coastal Domain: a unifying concept. Prog. Oceanogr. 139, 13-23. doi: 10.1016/j.pocean.2015.07.014

Clough, L. M., Ambrose, W. G., Cochran, J. K., Barnes, C., Renaud, P. E., and Aller, R. C. (1997). Infaunal density, biomass and bioturbation in the sediments of the Arctic Ocean. Deep-Sea Res. Part II Top. Stud. Oceanogr. 44, 1683-1704. doi: 10.1016/S0967-0645(97)00052-0

Conmy, R. N. (2008). Temporal and Spatial Patterns in Optical Properties of Colored Dissolved Organic Matter on Florida's Gulf Coast: Shelf to Stream to Aquifer. Ph.D. thesis, University of South Florida.

Cooper, L. W., Benner, R., McClelland, J. W., Peterson, B. J., Holmes, R. M., Raymond, P. A., et al. (2005). Linkages among runoff, dissolved organic carbon, and the stable oxygen isotope composition of seawater and other water mass indicators in the Arctic Ocean. J. Geophys. Res.-Biogeosci. 110, G02013. doi: 10.1029/2005JG000031

Cooper, L. W., Whitledge, T. E., Grebmeier, J. M., and Weingartner, T. (1997). The nutrient, salinity, and stable oxygen isotope composition of Bering and Chukchi Seas waters in and near the Bering Strait. J. Geophys. Res.-Oceans 102, 12563-12573. doi: 10.1029/97JC00015

Davis, J., and Benner, R. (2005). Seasonal trends in the abundance, composition and bioavailability of particulate and dissolved organic matter in the Chukchi/Beaufort Seas and western Canada Basin. Deep-Sea Res. Part II Top. Stud. Oceanogr. 52, 3396-3410. doi: 10.1016/j.dsr2.2005.09.006

Del Castillo, C. E., and Coble, P. G. (2000). Seasonal variability of the colored dissolved organic matter during the 1994-95 NE and SW monsoons in the Arabian Sea. Deep-Sea Res. Part II Top. Stud. Oceanogr. 47, 1563-1579. doi: 10.1016/S0967-0645(99)00154-X

Druffel, E. R. M., Williams, P. M., Bauer, J. E., and Ertel, J. R. (1992). Cycling of dissolved and particulate organic matter in the open Ocean. J. Geophys. Res.-Oceans 97, 15639-15659. doi: 10.1029/92JC01511

Eicken, H. (2004). "The role of Arctic sea ice in transporting and cycling terrestrial organic matter," in The Organic Carbon Cycle in the Arctic Ocean, eds R. Stein and R. W. MacDonald (Berlin: Springer-Verlag), 45-53.

Eicken, H., Gradinger, R., Gaylord, A., Mahoney, A., Rigor, I., and Melling, H. (2005). Sediment transport by sea ice in the Chukchi and Beaufort Seas: increasing importance due to changing ice conditions? Deep-Sea Res. Part II Top. Stud. Oceanogr. 52, 3281-3302. doi: 10.1016/j.dsr2.2005.10.006

Fellman, J. B., D'Amore, D. V., and Hood, E. (2008). An evaluation of freezing as a preservation technique for analyzing dissolved organic C, N and $\mathrm{P}$ in surface water samples. Sci. Total Environ. 392, 305-312. doi: 10.1016/j.scitotenv.2007.11.027

Fichot, C. G., and Benner, R. (2011). A novel method to estimate DOC concentrations from CDOM absorption coefficients in coastal waters. Geophys. Res. Lett. 38, L03610. doi: 10.1029/2010GL046152

Fichot, C. G., and Benner, R. (2014). The fate of terrigenous dissolved organic carbon in a river-influenced ocean margin. Global Biogeochem. Cycles 28, 1-19. doi: 10.1002/2013GB004670

Fichot, C. G., Benner, R., Kaiser, K., Shen, Y., Amon, R. M., Ogawa, H., et al. (2016). Predicting dissolved lignin phenol concentrations in the coastal ocean from chromophoric dissolved organic matter (CDOM) absorption coefficients. Front. Mar. Sci. 3:7. doi: 10.3389/fmars.2016.00007

Fichot, C. G., Kaiser, K., Hooker, S. B., Amon, R. M. W., Babin, M., Bélanger, S., et al. (2013). Pan-Arctic distributions of continental runoff in the Arctic Ocean. Sci. Rep. 3:1053. doi: 10.1038/srep01053

Giannelli, V., Thomas, D. N., Haas, C., Kattner, G., Kennedy, H., and Dieckmann, G. S. (2001). Behaviour of dissolved organic matter and inorganic nutrients during experimental sea-ice formation. Ann. Glaciol. 33, 317-321. doi: $10.3189 / 172756401781818572$

Gordon, D. C., and Cranford, P. J. (1985). Detailed distribution of dissolved and particulate organic matter in the Arctic Ocean and comparison with other oceanic regions. Deep-Sea Res. Part I 32, 1221-1232. doi: 10.1016/01980149(85)90005-6

Gosselin, M., Levasseur, M., Wheeler, P. A., Horner, R. A., and Booth, B. C. (1997). New measurements of phytoplankton and ice algal production in the Arctic Ocean. Deep-Sea Res. Part II Top. Stud. Oceanogr. 44, 1623-1644. doi: 10.1016/S0967-0645(97)00054-4

Gradinger, R. (2009). Sea-ice algae: major contributors to primary production and algal biomass in the Chukchi and Beaufort Seas during May/June 2002. Deep-Sea Res. Part II Top. Stud. Oceanogr. 56, 1201-1212. doi: 10.1016/j.dsr2.2008.10.016

Granskog, M. A., Stedmon, C. A., Dodd, P. A., Amon, R. M., Pavlov, A. K., Steur, L., et al. (2012). Characteristics of colored dissolved organic matter (CDOM) in the Arctic outflow in the Fram Strait: assessing the changes and fate of terrigenous CDOM in the Arctic Ocean. J. Geophys. Res.-Oceans 117, C12. doi: 10.1029/2012JC008075

Griffith, D. R., McNichol, A. P., Xu, L., McLaughlin, F. A., MacDonald, R. W., Brown, K. A., et al. (2012). Carbon dynamics in the western Arctic Ocean: insights from full-depth carbon isotope profiles of DIC, DOC, and POC. Biogeosciences 9, 1217-1224. doi: 10.5194/bg-9-1217-2012

Guay, C. K., Falkner, K. K., Muench, R. D., Mensch, M., Frank, M., and Bayer, R. (2001). Wind-driven transport pathways for Eurasian Arctic river 
discharge. J. Geophys. Res.-Oceans 106, 11469-11480. doi: 10.1029/2000JC0 00261

Guay, C. K., Klinkhammer, G. P., Falkner, K. K., Benner, R., Coble, P. G., Whitledge, T. E., et al. (1999). High-resolution measurements of dissolved organic carbon in the Arctic Ocean by in situ fiber-optic spectrometry. Geophys. Res. Lett. 26, 1007-1010. doi: 10.1029/1999GL900130

Guéguen, C., Guo, L. D., Yamamoto-Kawai, M., and Tanaka, N. (2007). Colored dissolved organic matter dynamics across the shelf-basin interface in the western Arctic Ocean. J. Geophys. Res.-Oceans 112, C5. doi: 10.1029/2006JC003584

Guéguen, C., Itoh, M., Kikuchi, T., Eert, J., and Williams, W. J. (2015). Variability in dissolved organic matter optical properties in surface waters in the Amerasian Basin. Front. Mar. Sci. 2:78. doi: 10.3389/fmars.2015.00078

Hansell, D. A., and Carlson, C. A. (1998). Deep-ocean gradients in the concentration of dissolved organic carbon. Nature 395, 263-266. doi: $10.1038 / 26200$

Hansell, D. A., Kadko, D., and Bates, N. R. (2004). Degradation of terrigenous dissolved organic carbon in the western Arctic Ocean. Science 304, 858-861. doi: 10.1126/science.1096175

Hudson, N., Baker, A., Reynolds, D. M., Carliell-Marquet, C., and Ward, D. (2009). Changes in freshwater organic matter fluorescence intensity with freezing/thawing and dehydration/rehydration. J. Geophys. Res. 114, G00F08. doi: 10.1029/2008JG000915

Jakobsson, M., Grantz, A., Kristoffersen, Y., and Macnab, R. (2004). "Physiography and bathymetry of the Arctic Ocean," in The Organic Carbon Cycle in the Arctic Ocean, eds R. Stein and R. MacDonald (Berlin: Springer-Verlag), 1-6.

Jones, E. P., and Anderson, L. G. (1986). On the origin of the chemicalproperties of the Arctic-ocean halocline. J. Geophys. Res.-Oceans 91, 759-767. doi: 10.1029/jc091ic09p10759

Jones, E., Rudels, B., and Anderson, L. (1995). Deep waters of the Arctic Ocean: origins and circulation. Deep-Sea Res. Part I 42, 737-760. doi: 10.1016/09670637(95)00013-V

Kaiser, K., and Benner, R. (2012). Organic matter transformations in the upper mesopelagic zone of the North Pacific: chemical composition and linkages to microbial community structure. J. Geophys. Res. 117, C01023. doi: 10.1029/2011JC007141

Kattner, G., Lobbes, J. M., Fitznar, H. P., Engbrodt, R., Nöthig, E. M., and Lara, R. J. (1999). Tracing dissolved organic substances and nutrients from the Lena River through Laptev Sea (Arctic). Mar. Chem. 65, 25-39. doi: 10.1016/S03044203(99)00008-0

Kim, T.-H., Kim, G., Lee, S.-A., and Dittmar, T. (2015). Extraordinary slow degradation of dissolved organic carbon (DOC) in a cold marginal sea. Sci. Rep. 5:13808. doi: 10.1038/srep13808

Klages, M., Boetius, A., Christensen, J., Deubel, H., Piepenburg, D., Schewe, I., et al. (2004). "The benthos of Arctic seas and its role for the organic carbon cycle at the seafloor," in The Organic Carbon Cycle in the Arctic Ocean, eds R. Stein and R. MacDonald (Berlin: Springer-Verlag), 139-167.

Krembs, C. E., Eicken, H., Junge, K., and Deming, J. (2002). High concentrations of exopolymeric substances in Arctic winter sea ice: implications for the polar ocean carbon cycle and cryoprotection of diatoms. Deep-Sea Res. Part I 49, 2163-2181. doi: 10.1016/S0967-0637(02)00122-X

Letscher, R. T., Hansell, D. A., and Kadko, D. (2011). Rapid removal of terrigenous dissolved organic carbon over the Eurasian shelves of the Arctic Ocean. Mar. Chem. 123, 78-87. doi: 10.1016/j.marchem.2010.10.002

Logvinova, C. L., Frey, K. E., and Cooper, L. W. (2016). The potential role of sea ice melt in the distribution of chromophoric dissolved organic matter in the Chukchi and Beaufort Seas. Deep-Sea Res. Part II Top. Stud. Oceanogr. 130, 28-42. doi: 10.1016/j.dsr2.2016.04.017

MacDonald, R. W., Paton, D. W., Carmack, E. C., and Omstedt, A. (1995). The freshwater budget and under-ice spreading of Mackenzie River water in the Canadian Beaufort Sea based on salinity and ${ }^{18} \mathrm{O} /{ }^{16} \mathrm{O}$ measurements in water and ice. J. Geophys. Res. 100, 895-919. doi: 10.1029/94JC 02700

Mathis, J. T., Hansell, D. A., and Bates, N. R. (2005). Strong hydrographic controls on spatial and seasonal variability of dissolved organic carbon in the Chukchi Sea. Deep-Sea Res. Part II Top. Stud. Oceanogr. 52, 3245-3258. doi: 10.1016/j.dsr2.2005.10.002
Mathis, J. T., Hansell, D. A., Kadko, D., Bates, N. R., and Cooper, L. W. (2007). Determining net dissolved organic carbon production in the hydrographically complex western Arctic Ocean. Limnol. Oceanogr. 52, 1789-1799. doi: 10.4319/lo.2007.52.5.1789

Melling, H., and Moore, R. M. (1995). Modification of halocline source waters during freezing on the Beaufort Sea shelf: evidence from oxygen isotopes and dissolved nutrients. Cont. Shelf Res. 15, 89-113. doi: 10.1016/02784343(94)P1814-R

Melnikov, I. A. (1997). The Arctic Sea Ice Ecosystem. Amsterdam: Gordon and Breach Science Publisher.

Morison, J., Kwok, R., Peralta-Ferriz, C., Alkire, M., Rigor, I., Andersen, R., et al. (2012). Changing arctic ocean freshwater pathways. Nature 481, 66-70. doi: 10.1038 /nature 10705

Mysak, L. A. (2001). Patterns of Arctic circulation. Science 293, 1269-1270. doi: 10.1126/science. 1064217

Nakayama, Y., Fujita, S., Kuma, K., and Shimada, K. (2011). Iron and humictype fluorescent dissolved organic matter in the Chukchi Sea and Canada Basin of the western Arctic Ocean. J. Geophys. Res.-Oceans 116, C7. doi: 10.1029/2010JC006779

Nelson, N. B., Siegel, D. A., Carlson, C. A., and Swan, C. M. (2010). Tracing global biogeochemical cycles and meridional overturning circulation using chromophoric dissolved organic matter. Geophys. Res. Lett. 37, L03610. doi: 10.1029/2009GL042325

Opsahl, S., Benner, R., and Amon, R. M. W. (1999). Major flux of terrigenous dissolved organic matter through the Arctic Ocean. Limnol. Oceanogr. 44, 2017-2023. doi: 10.4319/lo.1999.44.8.2017

Parkinson, C. L., and Comiso, J. C. (2013). On the 2012 record low Arctic sea ice cover: combined impact of preconditioning and an August storm. Geophys. Res. Lett. 40, 1356-1361. doi: 10.1002/grl.50349

Proshutinsky, A. Y., and Johnson, M. A. (1997). Two circulation regimes of the wind-driven Arctic Ocean. J. Geophys. Res.-Oceans 102, 12493-12514. doi: 10.1029/97JC00738

Rachold, V., Eicken, H., Gordeev, V., Grigoriev, M. N., Hubberten, H.-W., Lisitzin, A. P., et al. (2004). "Modern terrigenous organic carbon input to the Arctic Ocean," in The Organic Carbon Cycle in the Arctic Ocean, eds R. Stein and R. MacDonald (Berlin: Springer-Verlag), 33-55.

Robbins, L. L., Wynn, J. G., Lisle, J. T., Yates, K. K., Knorr, P. O., Byrne, R. H., et al. (2013a). Baseline monitoring of the Western Arctic Ocean estimates 20\% of Canadian Basin surface waters are undersaturated with respect to aragonite. PLoS ONE 8:e73796. doi: 10.1371/journal.pone.0073796

Robbins, L. L., Wynn, J., Knorr, P. O., Onac, B., Lisle, J. T., McMullen, K., et al. (2014). USGS Arctic Ocean Carbon Cruise 2012: Field Activity L-01-12-AR to Collect Carbon Data in the Arctic Ocean, August-September 2012. Reston, VA: U.S. Geological Survey Data Series, 862. doi: 10.3133/ds862

Robbins, L. L., Yates, K. K., Gove, M. D., Knorr, P. O., Wynn, J., Byrne, R. H., et al. (2013b). USGS Arctic Ocean Carbon Cruise 2010, Field Activity H-3-10-AR to Collect Carbon Data in the Arctic Ocean, August- September 2010. Reston, VA: U.S. Geological Survey Data Series, 741. Available online at: http://pubs.usgs. gov/ds/741/

Robbins, L. L., Yates, K. K., Knorr, P. O., Wynn, J., Lisle, J. T., Buczkowski, B., et al. (2013c). USGS Arctic Ocean Carbon Cruise 2011, USGS Field Activity H01-11-AR to Collect Carbon Data in the Arctic Ocean, August-September 2011. Reston, VA: U.S. Geological Survey Data Series, 748. Available online at: http:// pubs.usgs.gov/ds/748/

Rudels, B. (2009). "Arctic Ocean Circulation," in Encyclopedia of Ocean Sciences, 2nd Edn., eds J. H. Steele, S. A. Thorpe, and K. K. Turekian (Oxford: Academic Press), 211-225.

Rudels, B., Anderson, L., and Jones, E. (1996). Formation and evolution of the surface mixed layer and halocline of the Arctic Ocean. J. Geophys. Res. 101, 8807-8821. doi: 10.1029/96JC00143

Rudels, B., Jones, E. P., Schauer, U., and Eriksson, P. (2004). Atlantic sources of the Arctic Ocean surface and halocline waters. Polar Res. 23, 181-208. doi: 10.1111/j.1751-8369.2004.tb00007.x

Rutgers van der Loeff, M. M., Key, R. M., Scholten, J., Bauch, D., and Michel, A. (1995). ${ }^{228} \mathrm{Ra}$ as a tracer for shelf water in the Arctic Ocean. Deep-Sea Res. Part II Top. Stud. Oceanogr. 42, 1533-1553. doi: 10.1016/0967-0645(95) 00053-4 
Shen, Y., Fichot, C. G., and Benner, R. (2012). Dissolved organic matter composition and bioavailability reflect ecosystem productivity in the Western Arctic Ocean. Biogeosciences 9, 4993-5005. doi: 10.5194/bg-9-4993-2012

Shimada, K., Itoh, M., Nishino, S., McLaughlin, F., Carmack, E., and Proshutinsky, A. (2005). Halocline structure in the Canada Basin of the Arctic Ocean. Geophys. Res. Lett. 32, 3. doi: 10.1029/2004GL021358

Smith, R., Gosselin, M., Kudoh, S., Robineau, B., and Taguchi, S. (1997). DOC and its relationship to algae in bottom ice communities. J. Mar. Syst. 11, 71-80. doi: 10.1016/S0924-7963(96)00029-2

Song, G., Xie, H., Aubry, C., Zhang, Y., Gosselin, M., Mundy, C., et al. (2011). Spatiotemporal variations of dissolved organic carbon and carbon monoxide in first-year sea ice in the western Canadian Arctic. J. Geophys. Res.-Oceans 116, C9. doi: 10.1029/2010JC006867

Spencer, R. G., Bolton, L., and Baker, A. (2007). Freeze/thaw and pH effects on freshwater dissolved organic matter fluorescence and absorbance properties from a number of UK locations. Water Res. 41, 2941-2950. doi: 10.1016/j.watres.2007.04.012

Spencer, R. G. M., Hernes, P. J., Ruf, R., Baker, A., Dyda, R. Y., Stubbins, A., et al. (2010). Temporal controls on dissolved organic matter and lignin biogeochemistry in a pristine tropical river, Democratic Republic of Congo. J. Geophys. Res. 115, G03013. doi: 10.1029/2009JG001180

Stedmon, C., Amon, R., Rinehart, A., and Walker, S. (2011). The supply and characteristics of colored dissolved organic matter (CDOM) in the Arctic Ocean: pan Arctic trends and differences. Mar. Chem. 124, 108-118. doi: 10.1016/j.marchem.2010.12.007

Steele, M., and Boyd, T. (1998). Retreat of the cold halocline layer in the Arctic Ocean. J. Geophys. Res.-Oceans 103, 10419-10435. doi: 10.1029/98JC00580

Steele, M., Morison, J., Ermold, W., Rigor, I., Ortmeyer, M., and Shimada, K. (2004). Circulation of summer Pacific halocline water in the Arctic Ocean. J. Geophys. Res.-Oceans 109, C02027. doi: 10.1029/2003jc002009

Tanhua, T., Jones, E. P., Jeansson, E., Jutterström, S., Smethie, W. M., Wallace, D. W., et al. (2009). Ventilation of the Arctic Ocean: mean ages and inventories of anthropogenic $\mathrm{CO}_{2}$ and CFC-11. J. Geophys. Res.-Oceans 114, C1. doi: 10.1029/2008JC004868

Thomas, D. N., Lara, R. J., Eicken, H., Kattner, G., and Skoog, A. (1995). Dissolved organic matter in Arctic multi-year sea ice during winter: major components and relationship to ice characteristics. Polar Biol. 15, 477-483. doi: 10.1007/bf00237461

Wheeler, P. A., Watkins, J. M., and Hansing, R. L. (1997). Nutrients, organic carbon and organic nitrogen in the upper water column of the Arctic Ocean: implications for the sources of dissolved organic carbon. Deep-Sea Res. Part II Top. Stud. Oceanogr. 44, 1571-1592.

Woodgate, R. A., and Aagaard, K. (2005). Revising the bering strait freshwater flux into the Arctic Ocean. Geophys. Res. Lett. 32, L02602. doi: 10.1029/2004gl021747

Yamamoto-Kawai, M., McLaughlin, F., Carmack, E., Nishino, S., and Shimada, K. (2008). Freshwater budget of the Canada Basin, Arctic Ocean, from salinity, $\delta^{18} \mathrm{O}$, and nutrients. J. Geophys. Res. 113, C01007. doi: 10.1029/2006JC0 03858

Yamashita, Y., Maie, N., Briceño, H., and Jaffé, R. (2010). Optical characterization of dissolved organic matter in tropical rivers of the Guayana Shield, Venezuela. J. Geophys. Res. 115, G00F10. doi: 10.1029/2009JG0 00987

Conflict of Interest Statement: The authors declare that the research was conducted in the absence of any commercial or financial relationships that could be construed as a potential conflict of interest.

Copyright (C) 2016 Shen, Benner, Robbins and Wynn. This is an open-access article distributed under the terms of the Creative Commons Attribution License (CC BY). The use, distribution or reproduction in other forums is permitted, provided the original author(s) or licensor are credited and that the original publication in this journal is cited, in accordance with accepted academic practice. No use, distribution or reproduction is permitted which does not comply with these terms. 